\title{
F 466 S55
}
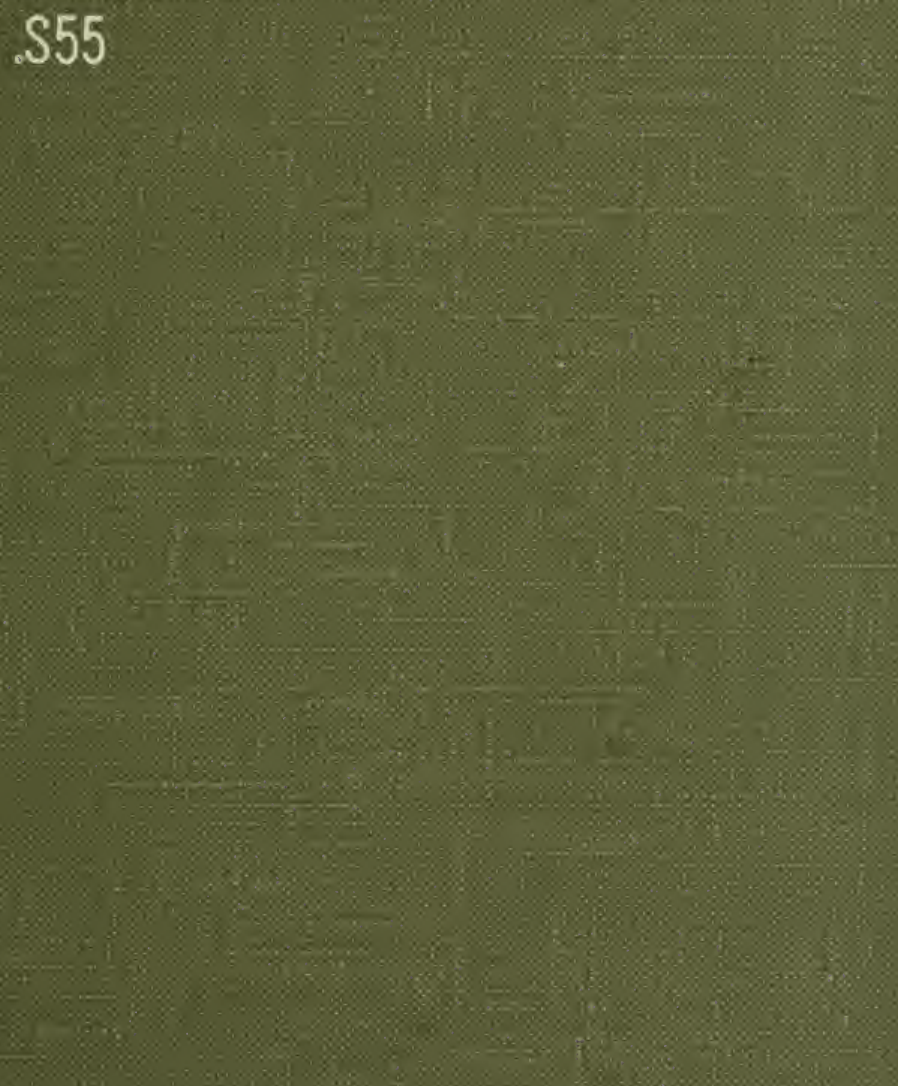



\section{SHEWEY'S \\ GUIDE AND MAP}

To rHE

HAPPY HUNTING GROUNDS

MISSOURI AND ARKANSAS.

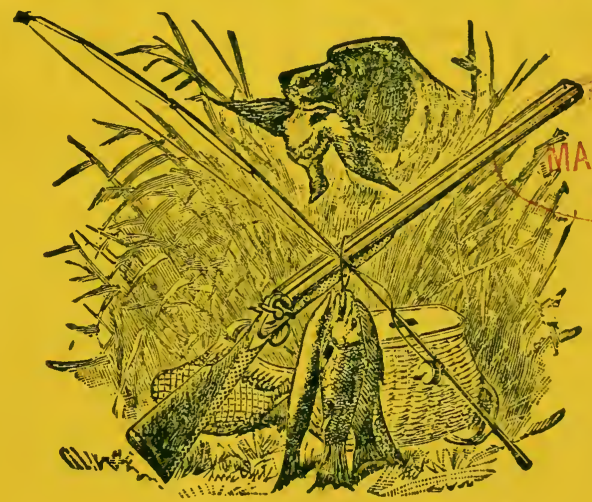

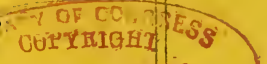
$R 2818921$
$6227 \times 1$

The Paradise of the Hunter and Fisherman.

\section{ARISTA C. SHEWEY,}

MAP PUII-ISHHER,

AND DEALER IN ALL KINDS OF MAPS.

714 Pine Street.

ST. LOUIS, MO. 
Tisfing and Fing anting. IERT TIED

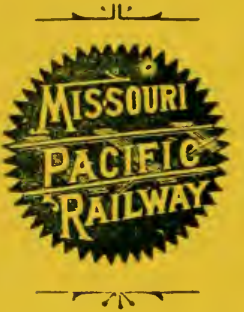

Huntirig Grounds of Southeast Missouri

$$
\begin{aligned}
& \text { and Arkansas. } \\
& \text { Trex TxxE }
\end{aligned}
$$

Lakes, Rivers and Streams of Southeast Missouri and Arkansas.

\section{THIS REGION ABOUNDS IN GAME AND GAME FISH.}

The following Rivers are Reached by this Route. MERAMEC RIVER, BiG RIVER, ST. FRANCIS RIVER, BLACK RIVER,
CURRENT RIVER,

CASTOR RIVER,

GREEN RIVER,

CACHE RIVER,
WHITE RIVER, WACHITA RIVER, LITTLE RIVER, L'ANGUILLE RIVER,

ELEVEN POINT RIVER, STRAWBERRY RIVER.

REDUCED ROUND TRIP HUNTERS' RATES

TO ALL POINTS

-VIA-

IRON

MOUNTAIN

ROUTE.

For a Guide to the Hunting and Fishing Resorts, Address,

H. C. TOWNSEND, Gen'i Pass, and Ticket hgt, S'T. LOUIS, MO. 
$\Xi \subseteq L I D$
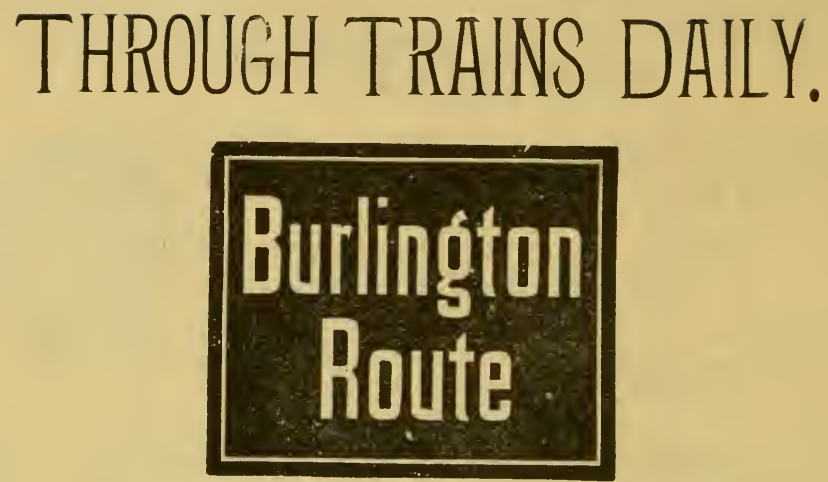

FROM ST. LOUIS, TO

Kansus City, St. Joseph, Denver St. Paul and Minneapolis.

THE BEST LING FROTM

St. Louis to Cheyenn! and the Black Hills.

Only One Change of Cars from St. Louis to the Pabiiie Coast,

VIA

DENVER OR ST. PAUL.

TrCket Offices:

218 N. Broaduay and Union Depot. 


\section{POCKET STATE MAPS.}

\section{"CRAM'S" \\ SHOWS THE RAILWAY SYSTEM IN COLORS.}

Printed on BOND PAPER, and will not break and become useless after being folded a few times.

\begin{tabular}{|c|c|c|}
\hline Alabama. & & ta \\
\hline dlaska, $26 x 36$ inches ........... & 1.00 & Ohio .... \\
\hline Arizona & .25 & \\
\hline 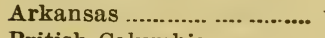 & .25 & \\
\hline Columbia................. & .25 & \\
\hline 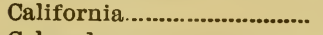 & .25 & $P$ \\
\hline 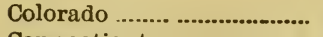 & .25 & \\
\hline (n......................... & .25 & ........ \\
\hline 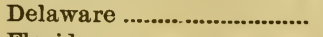 & .25 & ...... \\
\hline 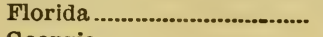 & .2 & c...... \\
\hline -........... & .25 & ..... \\
\hline n................. & .25 & $T$ \\
\hline & .25 & $\mathrm{Ur}$ \\
\hline . & .25 & $\cdots$ \\
\hline Territory .............. & .25 & $1 \ldots . . .$. \\
\hline (n).................. & .25 & ...... \\
\hline (n.............. & .25 & $\ldots$ \\
\hline - & .25 & \\
\hline (n.................... & 2 & $\ldots$ \\
\hline n............. & 2 & $\cdots$ \\
\hline 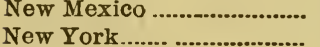 & 25 & 我 \\
\hline rth Carolina & .25 & $\ldots$ \\
\hline
\end{tabular}

STATE IMAPS-The above Map, $18 \times 22$ inches, mounted on binder's board. For handy reference about the desk. Prioe each, 50 cents.

\section{JOHNSON'S CLASSICAL AND SCRIP- TURAL GEOGRAPHY.}

WITH NAMES.

Size, $42 \times 50$ inches. Price per Map, $\$ 5.00$.

Oribus, Veteribus, Italia Antiqua, Asia Minor, Orbis Romanus, Cæsar de Bello Gallico, Tavels in St. Paul. Outline Map bordering on the Mediterranean, Canaan and Palestine Bible Countries. 


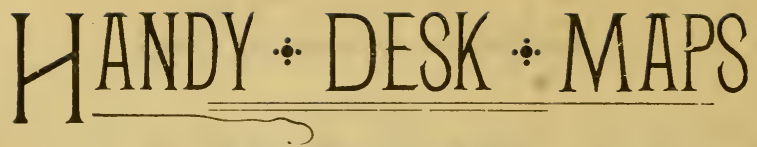

\section{OF EACH STATE,}

TNOUNTED ON TARBOARD

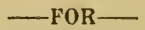

\section{OFFICE USE AND FOR SHIPPERS}

Are very durable, and will stand any amount of handling and abuse, and are for quick use.

THE Railway Systems are in Separate Colors, each color representing a System, making it much more easily to tarce a line, see the Junction points and connections than on the old style maps. On each map is a Special Index to find any railroad however small and remote, instantly.

An index accompanies each map, giving every town, village, hamlet and cross roads, with the population, Express, Telegraph, Money Order offices, Banking towns, etc.

Price, single map, on board, - $\$ .60$ " two maps, on board, - 1.00

\section{SIZE OF MAPS, $18 \times 24$ INCHES.}

The following named states we can give twice the size, $24 \times 36$ inches, and can put any two of the $18 \times 24$ inch maps on the back:

N. Y., Pa., Ya, Ill., Tex., Ky. and Tenn.

Price, for three maps,

$\$ 1.50$

" for one large single map, on board, $\quad .85$

These large maps can je hinged to fold the size of the $18 \times 24$ inch maps for 15 cents additional.

\section{Arista C. Shewey,}

MAP PUBLISHER,

AND DEALER IN ALL KINDS OF Maps and Atlases.

CHICAGO OFFICE, 415 DEARBOAN ST. ST. LOUIS OFFICE, 714 PINE ST. 


\section{SHEWEY'S}

\section{GUIDE \& MAP \\ - TO THE}

\section{HUNTING AND}

\section{FISHING GROUNDS}

OF MISSOURI and ARKANSAS.

The Paradise of the Hunter and Fisherman

Game Laws of every State and Territory in the United States, British Columbia and the Provinces, with Maps of Missouri and Arkanșas.

\section{ARISTA C. SHEWEY,}

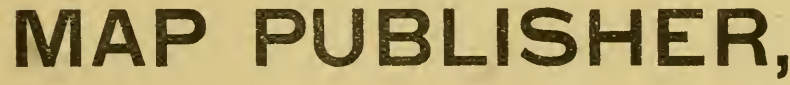

AND DEALER IN ALL KINDS OF MAPS.

714 Pine Street, ST. LOUIS, MO. 
Copyrighted 1892.

$-\mathrm{BY}-$

Arista C. Shewey.

$=466$

555 


\section{TABLE OF CONTENTS.}

Act to prohibit the exportation of game and fish

Page. Index
to Map. out of the State of Arkansas......... 6

Act to prohibit the exportation of game and fish

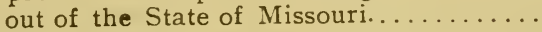

Amanzonia, Mo................... 21

American Rules for Trap Shooting. . . . . . . . 49

Ardeolia, Mo . . . . . . . . . . ......... 12

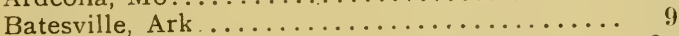

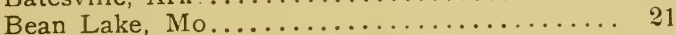

Bemis, Ark

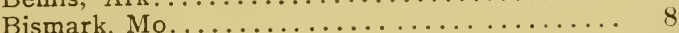

Chadwick, Mo..................... 16

Clarendon, Ark ....................... 14

Corning Ark .......... 8

Cotton Belt Route, Hunting and Fisbing along. . 12

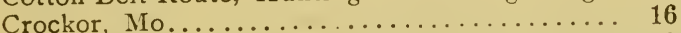

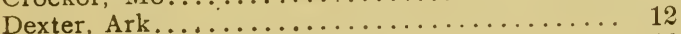

Frisco, Line Hunting and Fishing along........ 16

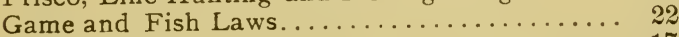

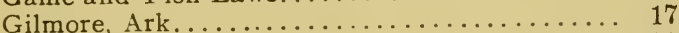

Hannibal, St. Joseph Ry. (Burlington Route).... 20

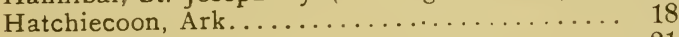

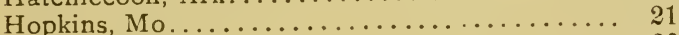

Horse Shoe Lake, Ill . . ................ 20

Idalia, Mo ........................ 12

Illinois Hunting and Fishing Points. . . . . . . . 19

Iron Mountain Route, Hunting and Fishing along 7

" . " " Hunters' Rates......... 10

“ " "

Jacksonville \& South Eastern Ry........... 19

Jerome, Mo. ..................... 16

$\mathrm{K}-12$

Jonesboro, Ark.......................... 13 D-17

Kansas City, Springfield \& Memphis Line, Hunt-

ing and Fishing along the .......... 17

Kansas City, Șt. Joseph \& Council Bluffs Ry (Bur-

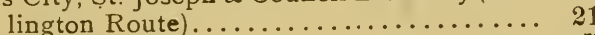

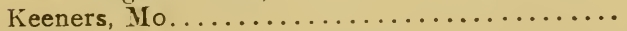

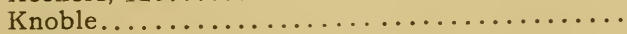

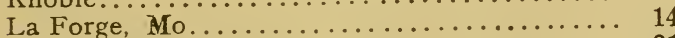

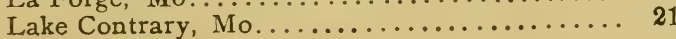

$\mathrm{K}-11$

$\mathrm{J}-12$

H-15

$\mathrm{E}-18$

A-4

O-19

.

(1)

$\begin{array}{ll} & \\ \mathrm{K}-12 \\ \mathrm{D}-17\end{array}$


Langdon, Mo............................... 21

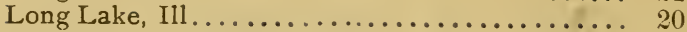

Malden, Mo......................... 12 O-2

Mammoth Springs, Ark.................. 17 A-14

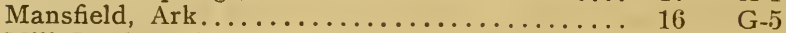

Mill Creek, Ark.................... 7 F. F

Neeleyville, Ark................. 7 P-17

Newport, Ark....................... 9 9.18

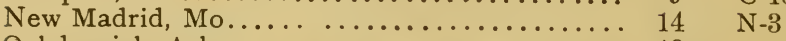

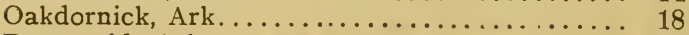

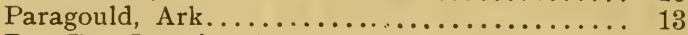

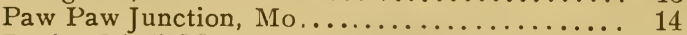

Poplar Bluff, Mo.................

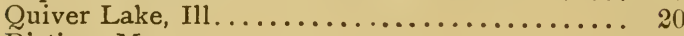

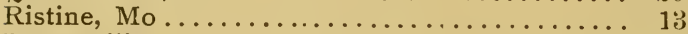

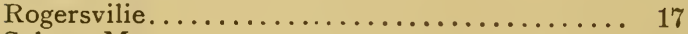

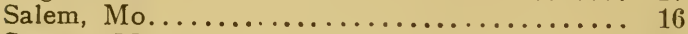

Seneca, Mo...................... 16

Spring Lake, Ill.................... 19

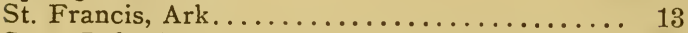

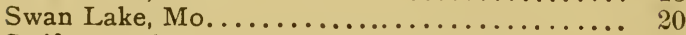

Swifton, Ark......................... 9

St. Louis, Arkansas \& Texas Ry ............ 15

Thayer, Mo .............................

\section{O-3}

O-17

N-8

P-20

Walnut Ridge, Mo.................... 8

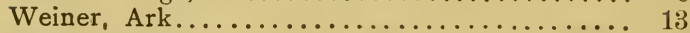

Williamsville, Mo..................

Winslow, Mo. 


\section{MISSOURI AND ARKANSAS,}

\section{THE PARADISE OF THE}

\section{HUNTER AND FISHERMAN.}

As the season approaches when the lover of the gun and rod anxiously consults the calendar which will once more legitimize this favorite sport, he asks himself with perplexity: Where shall I go this year? Where can I find a place which will fit my time, my pocket and my inclination?

To enable either the deciple of Nimrod or Sir Isitac Walton to choose a place where he can regale himself with the pleasure of hunting and fishing to his heart's lelight, we have completed accurate information as to the different resorts in Missomi and Arkansas, where good lotel and camping accommolations can be found with the character of the game and fish incident to such locality and means of reaching the same from St. Louis.

MISSOURI is still furnishing a very large propoltion of the game for the markets of all the larger cities of the United States. From October 15th to February $\because 1$ st of every year, there is not an express car arriving in St. Lonis which does not bring large consignments of gimie. Deer are numerous in the thinly settled mountainous districts, and also in the swampy districts of the southeistern part of the State. These lands and the Ozark mountains consititute the great deer park and game preserve. Game in the Ozarks, of all kinds, is most plentiful. It is joy to the Sportsman on arriving in this country to see the skins of deer and wild cats, foxes and minks, hanging on the posts in front of country stores, 
while the skins of bears and wolves are not infrequent. Small game is so plentiful that it is practically ignored by the natives.

\section{AN ACT TO PROHIBIT THE EXPORTATION OF GAME AND FISH OUT OF THE STATE OF MISSOURI:}

If any agent or servant of any railroad company, express company, steamboat or other com non carrier, or privat3 individual, have or recive for transportation or carriage, or for any other purpose, any of the birds or game hereinbefore mentioned, during the seaso: when the cat hilug, killing or injuring the same is prolibited, every such person shall be deemed guilty of a misdemeanor.

Revised Statutes OF 1889.

ARKANSAS is heavily eovered with woodlands, where not only the larger game, such as bear, deer and wild hog, but turkeys, ducks, grouse and quail are denizens, and the streams abound with salmon, black bass and ('oppie.

\section{AN ACT TO PROHIBIT THE EXPORTATION OF GAME AND FISH OUT OF THE STATE UF ARKANSAS}

Section 1. That all the game and flsh, except fish in private ponds found within the limits of this State, be, and the same is hereby declared tu ve, the property of this State; and the hunting, killing and catching of the same is declared to be a privilege.

Section 2. It shall be unlawful for any person to export any tish or game from this State until April 12,1895; and any person violating $t$ ie provisions of this Act shall be guil $y$ of a misdeme nor and shall $b$; fined, upon convi tio 1, in any sum not less thau twenty-five dollars and no; more than fifty dollars

Section 3. It shall be unlawful for any Railroad Company, steamboat, Express Company or any other common carrier to take for c.urriage any fish or gam ? consigned to points beyond the limits of this State.

Section 4. Any such c mmon carrier may refuse to receive any package which it may suppose contains fish or gamo desired for export, and may cause said p ickages to be opened, or may sati-fy themselves in any other way that said package does not contain game or fish.

Section 5. Any common carrier violating the provisions of this Act sh ill be deemed guilty of a misdemeanor, and upon con.

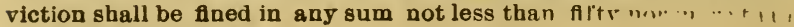
two hundred dollars. 
Section 6. Any violation of this Act shall be prosecuted in the name of the State of Arkansas, and one-half of the fine shall be paid into the rounty Treasury as other fines are requirhd to be raid, a'd the other half shall go to the informer.

Section 7. Justices of the Peace shall have jurisdi tion of prosecut ons under this Act.

section 8. All laws and parts of laws in confli $\cdot$ therewith are hereby refealed and this Act shall be in force from and after its passage.

Approved, A pril 12, 1889.

\section{AMENDMENT.}

Provi 1 that it shall not be unl wful under this Act to export b aver opossums, hares or rabbits ground hogs or wood chucks. rac onns squirrels, snipes or plover, provided the same shall $1 \mathrm{e}$ sh pped openly.

A pproved, March 31, 1891.

\section{HUNTING AND FISHING POINTS}

\section{•. on The.. \\ IRON MOUNTAIN ROUTE.}

Mill Creek, Williamsville, Keeners and Poplar Bluff are stations on the Iron Monutain Ronte in Southeast Missouri, and are also located on the banks of the Black River, which abounds in all kinds of game fish, and is every year visited by hundieds of anglers from a distance. West of these points, and a little more in the interior of Ozark Mountains, is a rapid mountain stream, the Current River. Here is found some of the finest trout fishing in all these regions. By a short land tour this river may be reached from any of the above points, or by rail from Williamsville. At Necleyville, itself a very good hunting and fishing point, a branch of the Iron Mountain extends to Doniphau. This point is situated on the banks of the Current River. It is the centre of the great game region of Southeast Missomri. and, in addition to the larger game a hunter is sure to bag turkeys, partridges, quail, squirrels, etc., which abound in 
great quantities. The Belmont branch of the Iron Mountitu Route extends from Bismarck, Mo., to Columbus, $\mathrm{Ky}$., passing through very desirable hunting ground, as does also the Cairo Branch, extending from Cairo to Poplar Bluff. If it is thought desirable to penetrate far from the railroad, a good method is to hire a freighter's wagon and driver who can cook. Plain food is cheap here, and a supply should be taken to last as long as the hunter desires to stay. From $\$ 2.00$ to $\$ 2.75$ per day will pay for the driver and his rig. Country hotel rates are $\$ 1.00$ per day, or from $\$ 4.00$ to $\$ 6.00$ per week.

\section{STATIONS IN ARKANSAS.}

Corning is the first noted hunting and fishing point in the State, and is known as the "Sportsmen's Retreat." "Deer Range," near the town, abounds in deer' (as its name implies), turkeys, ducks, squirrels and all the smaller. game. Corning Lake and the famous Blar.k River are well stocked with eroppie, perch, bass and pickerel. Boats can be obtained, and huts have been erected along the river, which are rented at a small cost to hunting parties.

Knobel has good hotel accommodations, game, deer, turkey, ducks, squirrel, etc. Black bass, jack salmon, croppie, perch, etc., are eaught in Mill Lake, Maiden Lake, Allen Lake, Black and Cache Rivers.

Walnut Ridge is the next good point below Knobel. Hotel accommodation, all kinds of game from deer down, in the Black and Cache River bottoms, and on the border's of the numerous lakes, in which are found, in large quantities, bass, perch, croppie, trout, buffalo and eat fish. Finest sporting grounds in the State. All the varieties of fish of Northern Arkansas are found in the Cache River and numerous lakes in the vicinity.

St. Francis River.-This River, flowing through Fastern Arkansas and emptying into the Mississippi above Helena, is the most famous duck-hunting resort in the 
United States. llocks of clucks, brant, geese, swan and smaller water fowl swarm the river and its backwaters, from Big Lake to its mouth, throughout the winter season. 'This river is accessible from Wynne, Earle and other points on the Memphis Extension, and from Forrest City and Marianna on the Helena Branch.

Swifton, farther south, has a large tract of thinly settled country, both to the east and west, that abounds in bear, deer, wolves, wild cats and all small game. Cat and buffalo fish, trout, bass, croppie, white and sun perch, are found in large quantities in Black, White, Cache and Strawberry Rivers, Hollingshead and Clear Lakes.

Newport is a large town, with good hotels and excellent hunting in the vicinity. All kinds of game, such as bear, deer, quail, teal, wood duck and mallards are very plentiful in season. Fish, such as black bass, croppie, jack salmon, channel cat, etc., are found in great quantities.

Batesville is west of Newport, on the White River Branch. It is a large town in a new and mountainous country, abounding in all kinds of game and fish. White River, Polk Bayo, Spring and Miller's Creeks and Spring Creek Lake, team with cat fish, goggle-eyed perch, trout, pike, striped bass, black bass, croppie, salmon, white perch, sturgeon, buffalo and drum fish. Hunting unsurpassed. Good hotels.

A letter from Samuel Cronin, Traveling Freight and Passenger Agent of the H. C. A. \& N. Railway, Alexander Division, which is a branch of the Iron Mountain System, and which was opened for business January 1st, says that this country is surely a sportsman's paradise. Deer are plenty and fish in abundance. Trout (they look like our bass) and perch can be easily caught in any of the little and apparently insignificant streams between the Ouachita and Red Rivers. The country is very sparsely settled and hunters should carry their supplies along, such 
as camp equipage, etc. The country is one vast forest of pine, oak and cypress, principally pine, between the above mentioned rivers.

\section{Hunters' Rates and Special Cars.}

Special rates found below have been made via the Iron Mountain Route to hunting parties of three or more. Tickets are good for thirty days, but not later than March 1st, in Missouri, and May 1st, in Arkansas, with stop overs at pleasure, and 150 pounds of baggage, including guns and dogs, will be carried free of charge. Hunting cars, having sleeping accommodations for about thirty, with cook, cooking utensils, dishes and full equipment, may be chartered by parties, and will be side-tracked at any point desired.

For further information, call on or address any of the Company's agents

\begin{tabular}{|c|c|c|}
\hline Augusta & $\begin{array}{l}\text { FROM CAIRO. } \\
\qquad S 40\end{array}$ & $\begin{array}{r}\text { FROM MEMRHIS. } \\
\$ 410\end{array}$ \\
\hline Beebe......................................... 1250 & 920 & 555 \\
\hline Charleston ............................ 710 & 100 & $\ldots \ldots$ \\
\hline Corning & 440 & 525 \\
\hline Crawfordsville & $83 \mathfrak{3}$ & 160 \\
\hline 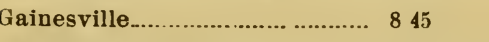 & 465 & 440 \\
\hline Harrisburg.................................... 1025 & 615 & 340 \\
\hline Hoxie........................................ 905 & $5 \%$ & ....... \\
\hline Knobel & 465 & 500 \\
\hline I'eeleyville................................. 725 & 395 & 570 \\
\hline Nettleton & 590 & 340 \\
\hline New port & $72 J$ & ....... \\
\hline Paragould ................................ 880 & $46 i$ & 415 \\
\hline Poplar Bluff............................ $6 \mathrm{t5}$ & $33 i$ & 630 \\
\hline wifton & 645 & ........ \\
\hline Wynne ....................................... 1120 & 710 & 280 \\
\hline
\end{tabular}




\section{VALUABLE ASSISTANCE.}

The fol'owi'g Traveling and Passenger Agents of the uIssourI PACI IC RAILWAT and IRON MOENISAIN ROOTE are constantly looking after the interests of the Line, and will call upon parties comtemplating a trip, and cheerfully furnish them lowest rate: of Fare, Maps, Guides, Land Pamphlets, Time Tables, etc. Or they may be addres:ed as follows.

ATCHISON, KAN.

C. E. STYLES

AUSTIN, TEX.

J. C. LEW I S

BOSTON, MASS.

G. K. DELAHAN'TY. New England Pass'r Agt., 300 Washington St

CAIRO, ILL.

J. W. MASON

CHATTANOOGA, TENN.

A A. GALLAGHE $\{$...Southern Passenger Agent, 1.3 head House CHICAGO, ILL.

JOHN E. ENNIS

CINCINNATI, OHIO.

N. K. WARWICK

DENVER, COL.

C. A. L'KIPP......General Western Freight and Passenger Agent

INDIANAPOLIS, IND.

COKE ALEXANDEk........ District Pass'r Agent, 7 Jackson Place JACKSON, MICH.

H. D. ARMS'TKONG

KANSAS CITY, MO.

E. S. JEWETI...............Passenger and Ticket Agent 033 Main St J. H. LYON

LEAVENWORTH, KAN.

J. N. JOERGEIR

LINCOLN, NEB.

R. Y. K, MILLAR

LITTLE ROCK, ARK.

H. F. BERKLEY

LOUISVILLE, KY.

L. E. DKAKE......

MEMPHIS, TENN.

H. D. WILSON

NEW YORK CITY.

W. E HOY I'...... General Eastern Passenger Agent, 391 Broadway

J.P. MCCANN

Western Passenger Agent, 533 Main St

Traveling Passenger Agent

MAHA, NEB.

J. O. PHILLIPPI.....Ass't Ge :eral Freight and Passenger Agent THO . F. GODF KEY, Pass'r \& 1 kt A At., N. E.cor. 13th \& Farham Sts PITTSBURGH, PA.

H. THOMPsON .............Central Passenger Agent 1119 Liberty St ST.JOSEPH, MO.

F. P. WADE:

ST. LOUIS, MO.

B. D. CALDWELL ........Ass't General Passenger and Ticket Agent

S. W. ELLIOTT.

II. GRIFFIN.

W. H. MORION.

Passenger and Ticket Agent General Agent

WICHITA, KAN.

E. E. BLECKLEY... Passenger and Tick t Agent, 120 N. Main St

S. H. H. CLARK,

IST VICE-PRES'T a GEN'L MGA.

H. C. TOWNSEND,

GEN.L PASS'R \& TKT. AOT.

ST. LOUIS, MO. 


\section{HUNTING AND FISHING}

\section{ON THE \\ COTTON BELT ROUTE.}

The Cotton Belt Route opens up this country, and makes what was formerly an impossible journey to the average man, a trifling matter of ten or twelve hours in a luxurious Pullman.

Leaving St. Louis 7:55 a. m., the first hunting points of any importance are Ardeola and Idalia, 166 and 176 miles from St. Louis, respectively. Here, within a few miles of the stations, deer and turkey are plentiful-not to mention the smaller game, which, in this region, is almost left to the small boy with his irrepressible muzzleloader.

Guides and teams, at a cost of from $\$ 2.00$ to $\$ 3.00$ per day for man and team, can be secured on application to the railroad agent.

Dexter, the next point, 185 miles from St. Louis, is situated in the midst of a beautiful track of prairie land, dotted here and there with islands of trees of from one to fifteen acres in extent. Here is the paradise of the quail and chicken hunter. Two miles in any direction from the station will start covey after covey, while at a distance of ten miles deer can be secured.

No guides are necessary, and teams and dogs can be procured in the town, which also provides good hotel accommodation at $\$ 1.50$ per day.

Malden, Mo., 202 miles from St. Louis, and 58 miles from Cairo, is the next point, thirty miles south from which, in the vicinity of Big Lake, the ideal of the sportsman is found. No clearing attests the domicile of man ; the settler's axe is as yet unhearl. The silence of the night is broken only by the solemn hooting of the owl or the blood-curdling screech of the panther. Bears hide in the thicket, and the graceful deer leap the fallen trees in 
the wild abandon of thoil fleedom. Willeat, fores, mink and wild hog are found, and turkey and smaller game are plentiful, while the lake and bayou swarm with flocks of duck, swan, geese, brant and other water-fowl.

Guides and teams can be secured at Malden, and hotel accommodations can be had at that point for $\$ 1.00$ per day and upwards.

At St. Francis, 213 miles from St. Louis and 70 miles from Cairo, the St. Francis river is crossed. This river abounds in black bass, jack salmon, croppie, perch, etc., and furnishes good duck shooting, while at a distance of 10 or 12 miles deer, turkey, etc., can be found. Guides and teams can be secured on application to the railroad agent.

At Paragould, Ark., 248 miles from St. Iouis and 103 miles from Cairo, a branch railroad runs out to St. Francis Lake, 10 miles distant. This lake furnishes excellent fishing, and duck, geese and brant cover its surface, while on Buffalo Island, across the lake, all kinds of game, including bear, deer and turkey, can be found. No guides or teams are necessary, as the Buffalo Island Railroad runs directly to the shores of the lake.

Between Paragould and Jonesboro, the land is covered with timber, and at various distances of from one to ten miles on both sides of the railroad are bayous, furnishing excellent duck shooting, while in the intervening woods deer and turkey are found. -

To go sonth of Jonesboro, it will be necessary to take the Cotton Belt night express, leaving St. Louis 8:20 p. m., and the principal points are Weiner. Fisher and Bemis. The surrounding country partakes of the same general characteristics as that described between Paragould and Jonesboro. The only abodes of man being an occasional saw-mill in the vicinity of the railroal.

At a distance of one mile from Bemis is Crooked Bayou. Fishing is excellent; duck, geese and water fowl in great numbers, and bear, deer, turkey and small game plentiful. 
Teams and guides can be hired on application to the railroad agents.

At Clarendon, 330 miles from St. Louis and 215 miles from Cairo, is the White River, in which fish of rarious kinds, principally trout, bass and croppie, can be found. Duck, geese and other water fowl are plentiful, while the banks and bottom Tands both east and west of the railroad furnish bear, deer and smaller game.

South of Clarendon commences the Grand Prairie of Arkansas, which can be reached from Roe, Ulm or Stuttgart. This prairie, 20 miles in width and 80 miles in length, dotted with islands of timber, provides the finest chicken and quail shooting in the West, while the bayous and bottom lands of the White and Arkansas Rivers, which bound the prairie on the north and south, are full of deer and turkey. Teams, etc., can be hired at UIm or Stuttgart.

Between Cairo and Malden are what is known as the sunk lands, vast marshy tracks, with ridges of dry lands, swarming with duck, geese, swan, brant and all varieties of water fowl. These lands can be reached from LaForge, Ristine, Paw Paw Junction or New Madrid. Good hotel accommodation can be had at New Madrid, also guides and boats.

The various sections of the country south of Malden partaking of the same general characteristics, it is hard to particularize any special spot as either the best or the most desirable, and as the localities which at one time during the season may abound in game, at other times may not be so well stocked, the best plan to pursue would be to purchase tickets to the farthest point which time and means will justify, and stop off at the intermediate points en route until a satisfactory location is found. This can easily be done, as Cotton Belt Hunter's' tickets provide for stop-off at pleasure both going and re. turning.

Beluw find conditions under which Hunters' tickets are sold; also round-trip rates from St. Louis and Cairo. 
Hunters' tickets will be sold to parties of three or more on one ticket, commencing Octobor 1st, limited to thirty days from the date of sale, but in no case later than March 1st to points in Missouri, or May 1st to points in Arkansas. Stop-over will be permitted to all points within the limit of the ticket, and guns, dogs and camping outtits to the amount of 200 pounds will be carried free for each passenger.

\section{HUNTERS' RATES}

\section{TO POINTS ON ST. LOUIS, ARKansas \& TEXas RaILWAY.}

\begin{tabular}{|c|c|c|}
\hline TO & $\begin{array}{l}\text { FROM } \\
\text { CAIRO. }\end{array}$ & $\begin{array}{l}\text { FROM } \\
\text { ST. LOUIS OR } \\
\text { E. ST. LOUIS. }\end{array}$ \\
\hline La Forge............. & $\$ 170$ & +870 \\
\hline (. & $20 \mathrm{~J}$ & 87. \\
\hline 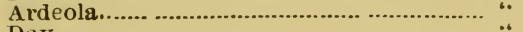 & ............... & 670 \\
\hline Day & .............. & 693 \\
\hline 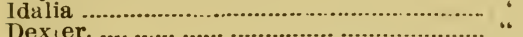 & ............. & 710 \\
\hline Dexier. & 285 & 740 \\
\hline 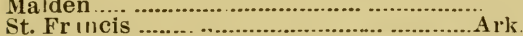 & 33 & $\begin{array}{ll}810 \\
865\end{array}$ \\
\hline Para $\_$ould ... & 465 & 875 \\
\hline e iboro .... & 5 & 950 \\
\hline 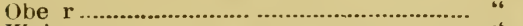 & 6 05 & 1015 \\
\hline (6) & $6: 35$ & 1045 \\
\hline Fisher........................ & 67 & 1085 \\
\hline ton & 721 & $113 \jmath$ \\
\hline Hunter .... & 800 & 1203 \\
\hline 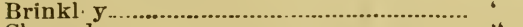 & $84 i$ & 1255 \\
\hline (............................ & 910 & 1320 \\
\hline . & 935 & 1345 \\
\hline 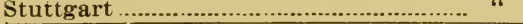 & 935 & 1395 \\
\hline
\end{tabular}

If hunting parties will notify any of the following, an Agent of the Company will meet them at St. Louis or Cairo, and render all assistance possible in the way of help and information.

\section{J. E. DAVENPORT,} CITY PASSENGEA AND TICKET AGENT.
S. G. HATCH, TRAVELING PASSENGEA AGENT.

NO. 215 NOATH FOUATh StAEET, St. LOUIS, MO.
J. H. JONES,
TICKET AGENT.

M. ADAMI,

, TAAVELING PASSENGER AGENT. CAIRO, ILLINOIS.

\section{MiLLER,} QENEAAL TAAFFIC MANAGER,
E. W. LaBEAUME, GENERAL PASSENGER AGENT

W. B. DODDRIDGE, GENERAL MANAGER. 


\section{HUNTING AND FISHING}

\section{ON THE \\ FRISCO LINE.}

It is a well known fact to sportsmen that there is no - section of the western eomntry th:t wfrords better hunting and lishing than Sonthwostern Missonri, Arkausas, Indian 'Lerritory and Southerm Kinssis, traversed by the Friseo Jine. The Meramec River, erossed several tines by this linc, atfords excelient fishing. The Gasconade and Little Pincy Rivers, crossed at Jerome, Mo., by this Line, are noted for their grurar fish. The James Rirer. near Spring. lield, Mo.. is another fine stream for fishing; the Spring River, near Vorona, Mo.; the Graud liver, near Seneca, Mo.: the Virdigris River, near Virdigris, I. 'I.; the White River, near Eureka Springs, Ark; the Kiamichi River, near Kosoma, I. T', all abound with game fish.

The hunting is good in all the connties of Southwest Missouri and Northwestern Arkansas. Large and small game of all kinds are plentiful, and no mistake ean be made by going to the Ozark, Boston and Kiamichi Mountains, on the Frisco Line, for excellent sport.

Enquire of game dealers in St. Lonis, and you will learn that the most game and greatest variety come from the Frisco Line.

This Line sells round-trip excursion tickets to parties of three or more on one solid ticket from October 1st to March 31st. Tickets are limited thirty days from date of sale. From St. Louis to, viz.:

Salem, Mo.......\$ $500 \mid$ Seneca, Mo....... \$13 00 Jerome, Mo........ 500 Winslow, Ark....... 1500 Crocker, Mo....... 590 St. Paul, Ark....... 1550 Chad wick, Mo...... $1100 \mid$ Mansfield, Ark..... 1790

For further particulars address nearest Station Agent of the Frisco Line, or D. Wishart, General Passenger Agent, St. Louis, Mo. 


\section{HUNTING AND FISHING GROUNDS}

\section{ALONG THE \\ Kansas City, Springfield \& Memphis Line}

IN SOUTHWESTERN MISSOURI AND ARKANSAS.

The statistics have been carefully gathered by iepresentative sportsmen who reside in that region, and much valuable information about the prospects for game, the kind of game that most abounds, the topography of the country, and the accommoditions and facilities offered to sportsmen. The reports generally show an abundance of game, including bear, deer, turkeys, ducks and quail, and also plenty of excellent fishing.

The best turkey and quail shooting is reported from Rogersville to Gilmore, a distance of 140 miles, turkey being so plentiful that the trainmen have no difficulty in bagging all they need for their own use from the track, where they come in flocks during the diry weather to seratch in the gravel along the line of the road. Deer are to be found in large quantities between Norwood and Hatchiecoon, but west of that range are scarcer.

Thayer, Oregon County, Missouri, is one of the first points on the line where game is reported to be plentiful. The hunting grounds in that vicinity extend over an area of about forty miles square, and are known to sportsmen as the celebrated Irish Wilderness aud Indian Camp. Deer, turkey, qnail and duck are thick, and the season will not elose until the latter part of February. Dogs and guides can be secured at reasonable rates by visiting sportsmen, and the hotel accommodations are good and charges low. There being no objection on the part of property owners to hunting on their grounds, this point is one of the best on the line for sport.

At Mammoth Springs in Arkausas, the game is plentiful orer a large territory; deer. turkey, quail and squirrel 
being the principal species, and quail and turkey being most numerous. The season extends over a period of three months, from November to February; guides can be secured at 50 cents per day, board at $\$ 1.00$ and livery $\$ 3.00$ per day. 'There are few dogs in the vicinity, however, and sportsmen who shoot over dogs exclusively will find it necessary to take their own. There are no objections made to hunters.

The hunting grounds in the neighborhood of Big Bay, in Craighead County, cover a radius of about twenty miles. There are some deer and an abundance of bear. Turkey aud duck are plentiful, and the season runs from September to May, while deer are shot as late as February, squirrel are also thick in that region, and hunters are not molested in that territory. Heavy breech-loading guns and Winchesters are suggested as the weapons to be used, and gum boots and rubber coats are necessary to a complete outfit.

Oakdornick is the name of the hunting grounds that are located at about a mile and a half from Hatchiecoon, and is the headquarters of the southern sportsmen, the Chickasaw Gunning and Trolling Club and the Osceola Ducking Club of Memphis, both having club-houses and leased grounds in that vicinity. The duck, turkey and squirrel shooting is excellent during the entire season, which runs from October 15 to February 1 , and there is a large lake near the Hatchiecoon, where the duck are very plentiful; it also affords rare sport for the angler. All that is necessary for the visiting sportsman is to get a permit from the secretary of either club, and the privilege is freely accorded.

At Big Creek, a mile or so out of Gilmore, there are plenty of bear, deer, turkey, duck and squirrel, and the fishing is the best in the Southwest. There being no hotels of any consequence in the neighborhood and the country unbroken and very sparsely settled, sportsmen visiting there will find a camp outfit necessary. The season lasts from October 15 to February 1, and the best time 
to visit that point is during November and December. Last year ducks were killed by the thousands, and they are just as plentiful now. Turkeys are also abundant and quite a number of bear and deer have been shipped out of Gilmore.

The hunting grounds are easily reached from Kansas City, the Fort Scott \& Gulf and Springfield \& Memphis line running directly through them. Sportsmen can leave this city at 6:30 in the evening and arrive at Thayer for breakfast the following morning, and if they desire to go further south, they reach Hatchiecoon by noon.

Special round-trip rates for hunting parties can be had on application to any ticket agent of the Fort Scott and Gulf line, or to the General Passenger Agent. Tents and Camp Equipage, if in convenient shape for handling and not of unreasonable weight, and carried free in baggage ('al'. For further information address,

\section{J. E. LOCKWOOD,}

General Passenger Agent,

Kansas City.

\section{Illinois Hunting and Fishing.}

Among the important Hunting and Fishing resorts Spring Lake, situated near Manito, on the Jacksonville \& Southeastern Railway, cannot be surpassed for its elegant fishing-bass, pickerel, croppie and other game fish are bountiful and aftord delighful sport.

Small game can be found in season, thereby affording good hunting. This lake is about 18 miles in length and from 100 yards to 8 -mile in width, and is within a short distance of Copperas Creek dam, located at government lock, "a beautiful resort." Upwards of fifty people can he comfortably accommodated at Spring Lake, and a large club house and hotel will be erected in a short time by 
the Pekin and Spring Lake Hunting and Fishing Club, which has recently been organized. Capital stock, $\$ 50,000$.

Quiver Lake is another resort on Illinois River, located near Havana, also affords splendid hunting and tishing. Ample accommodation for all.

Long Lake and Horse-Shoe Lake, wellknown resorts, are located on J. S. E. Line. These lakes are only about twelve miles from St. Lonis. Fishing is very good, boats, etc., can be obtained at the lakes.

In addition to above mentioned resorts, there are several others located on J. S. E. Line that furnish great sport.

Sport seekers rates the year around to all these places. Addless,

\section{H. A. SUTTLE,}

General Passenger Agent, 513 Chestnut St., St. Louis.

\section{HUNTING AND FISHING POINTS}

\section{ON THE}

\section{Hannibal \& St. Joseph Railway.}

\section{BURLINGTON ROUTE.}

Swan Lake, three and one-half miles south of Wheeling, Mo. Serisal good lakes on the "bottom" lands below "Swan Latke," rqualiy as good as Swan Lake. Good hotel aceommolations are afforded at Wheeling for those desiring to visit this locality.

There are two lakes, one $2 \frac{1}{2}$ miles, and the other three miles sonthwest of Utica, Mo. Good 
hotel accommodations. A number of timber lakes on the prairie near the same locality are equally good.

The bottom lands one and one-half miles east of Utica, Mo.. offers good inducements for duck hunting, as also other game. Good rabbit and quail hunting may be found in the vicinity of Holt, Kearney and Robertson, Mo.

A large lake with a variety of fish, three miles south of Liberty, with first-class facilities for fishing. Good hotel accommodations at Liberty.

Lake Contrary, one mile south of St. Joseph, affords good fishing. A good hotel being situated at the lake, boat houses, etc.

\section{POINTS ON THE}

\section{K.C., ST.J.\& C.B.R.R.}

\section{BURLINGTON ROUTE.}

Bean Lake, a point forty miles north of Kansas City, Mo., fine hunting and fishing. New hotel erected for accommodation for the benefit of people who go there to hunt and fish.

From Amazonia to Hopkins on the Hopkins Branch, and to Corning on the Main Line, good hunting and hotel accommodations at the different stations.

Langdon, the hunting and fishing is fine. This place has become quite a resort for the people in the county. Good accommodations can be had at all times. 


\section{THE OPEN SEASONS.}

The appended synopsis of the game and fish laws of all the States and Territories of the United States, and of the British Provinces.

\section{CAUTION.}

The Game. Laws printed herein are corrected up to August Ist, I 891 . Owing to frequent changes made at the session of each legislature, we would advise sportsmen and hunters to make inquiry from the State or Territorial officials to learn if any changes have been made.

ALABAMA. - In the counties or Monroe, Olarke, Wilcox, Talladega, Blbb, Autauga, Clay, deer, October 20 to February 14; wild turkeys, Ootober 20 to May 1; turtle doves, August 1 to April 1, and Montgomery County, July 10 to A pril 1; qualls or partridges, September 15 to March 15; ducks, October 1 to May 1. - In Perry County: doves, July 1 to March 15; quails, October 15 to March 15; deer, October 15 to Fobruary 15; duoks, October 1 to April 1; turkeys, October 20 to May 1. Moblle and Baldwin counties: deer, November 1 to February 1; turkeys and qualls, November 1 to April 1; turtle doves, September 1 to April 1; ducks, November 1 to May 1. Barbour County: deer, October 20 to May 1; quails, September 1 to May 1; turtle doves, August 1 to May 1. Butler and Elmore counties: deer, October 20 to February 15; turkeys, Uctober 20 to May 1; quails, September 15 to March 15; turtle doves, August 1 to April 1. Calhoun and Tuscaloosa counties: deer, turkeys and quails, November 1 to March 1; turtle doves, July 15 to March 1. Chilton and Sumter counties: deer September 15 to February 15; turkeys, September 15 to May 1; turtle doves, August 1 to March 15; quails, October 1 to April 1. Colbert, Cov ington, Jefferson, Lauderdale, Marengo, Pike and St. Clair counties: deer, September 1 to April 1; turkeys and quails, October 1 to April 1; quails protected in Covington County. Coosa County: deer, October 1 to April 1; tarkeys, October 1 to May. 1. Cullman, Limestone and Madison counties: deer, July 4 to February 1; turkegs and quails, September 1 to March 1. Dallas County: deer, October 20 to Fehtuary 4: turkeys, October 20 to A pril 1; turtle doves, July 10 to April 1; quails, October 10 to March 15. Greene County: deer, November 1 to Jąniary 10; turkeys, November 1 to Aprit 15; quails, Novembэr 1 to March 1; turtle dove November 1 to February 1. Hale County: deer, October 1 to February 1; turkeys, October 15 to May 1; qualls, March 15 to November 1; turtle doves, July 15 to March 15. Lawrence County: quaile, October 15 to March 25. Lowndes County: deer, October 20 to February 14; turkeys, October 20 to April 1; turtle doves, July 4 to April 1; quatle, October 10 to March 15. Macon County: deer, October 1 to February 1; turkeys, Ooto 
ber 1 to May 1; tartle doves, July 15 to April 1; quails, October 1 to March 1. Montgomery County: deer, October 2 J to February 14; turkeys, October 20 to May 1; turtle doves, July 10 to April 1; quails, October 15 to March 15; ducks, October 1 to May 1. Perry County: deer, October 15 to February 15; protected east of the Cahaba River. Turkeys, October 20 to May 1; turtle doves July 1 to March 15; quills, October 15 to March 15; ducks, October 1 to April 1. Pickens County: deer, September 15 to February 1; turkeys, September 15 to April 15; turtle doves, August 1 to April 1; quails, October 15 to March 15; ducks, October 1 to April 1. Camphunting, use of nets, traps and devlces.other than a shoulder gun, night hunting, floats, sneak boats, box or battery shoooting, prohibited in nearly every county. State law forbids Sunday shooting. Birds' nests and eggs protected, except those of birls of prey. Dims, trap3, weirs, or other obstructions to the free passage of fish up streams, and polsous, drugs and explosives prohibited

ALASKA. - The erection of dam ', barricades, or other obstructions, in any river, which would prevent fish from reaching their spawning grounds, prohibited.

ARIZONA.-Elks, deer, antelopes, mountain sheep, mountain goats, October 1 to February 1. Partridges, wild turkeys, geese, brants, swans, curlews, plovers, snipes, quails and ducks, September 1 to March 1. Prairie chickens or pinnated grouse protected to 1892 . The capture of flsh by means of nets or explosives prohibited.

ARKANSAS.-Deer, August 1 to February 1. Tur keys, 8eptember 1 to May 1. Prairie chickens, September 1 to February 1. Qualls, October 1 to March 1. Netting or snaring of quails, prairie chlckens and turkeys prohibited, except on a person's own premises during open season and at any time to protect fruit. Yell County, partridges and qualls, September 15 to March 15. Wild turkeys, August 15 to April 15. Nests of all birds protected except those of crows, blackbirds, hawks, owls, eagles and birds of prey. Yossession and transportation probibited during the close season. Exportation of game and fish prohibited until April 12, 1895, except beavers, opossums, hares or rabbits, ground hoge, woodchucks raccoons, squirrels, snipes and plovers, provided the same shafl be-shipped openly. All fish, except in private ponds, declared to be the property of the State, and catching same a privilege. Netting, seining, trapping, dragging or maintaining any obstructions in the waters of the State prohtbited: provided, small selnes may be used for catching minnows for bait; and for supplying necessary food. but not for sale, nets having meshes not less than three lnches in size may be used in riartgable waters. 
CALIFORNIA. - Deer, antelopes, elks and mountain sheөp protected until 1893. Quails, partridges, grouse of any kind, ducks and rails, October 1 to March 1. Doves, July 1 to January 1. Wild turkeys, Bob White quails, phesesnte and skylarks protecteal until January 1, 1895. Blue and white cranes protected. Netting and enaring of game and insectivorous birile prohibited : eggs and nests protected. Trout, A pril 1 to Novemaber 1 ; taking of trout, except with hook and line, prohibited. Salmon, October 1 to August 31. Fishing between $6 \mathrm{p}$. m. Saturday and sundowu of succeeding Sunday, prohibited. The pollurion of waters with linie, saw dust, drugs or any substance deleterious to flsh, and the use of explosives or any poisonons substance, or nets, welrs, traps or similar devices, prohibited. Marketing of shad weighing loss than eight pounds prohibited. Permiseion of owner of premises required in most counties to hu nt or flsh.

COLORADO.-Deer, elks and antelopes which have horns, July 1 to December 1. Not more than five deer, five antelopes and two elks a]. lowed to be killed iu any one year by one person, and hides of same may be shipped out of the State by obtaining a tag for each from the county clerk. The killing for food is limited to the immediate and necessary use of the person killing the animal, game bird or fish. Killing for market or sale prohibited. Hounding prohibited. Exportation of game and fish prohibited. Mountain sheөp protected until March 26 , 1897. Buffalos and mouncain goats protected until March 26, 1899. Prairie chickøns, grouse, qualls and pheasants, September 1 to Novem. ber 15. Ducks, brants, geese and swans, September 1 to April 1. Wild turkeys, larks, whip-poor-wills and all other song and inseotivorous birds protected. Owner's consent necessary to hunt in sny inclosure. Night hunting, netting and trapping prohibited. Trout or any food fish for immediate use, May 1 to December 1 . Fishing with hook and line only permitted. The use of explosives, drugs, nets, seines, weirs and the pollution of streams with sawdust or other deleterions substances, prohibited. The State is divided Into four game districts, with paid game and fish wardens.

CON NECTICUT.-Quails, woodcocks, ruffed grouse (called partridges), and gray squirrels, October 1 to January 1. Exportation of qualle, woodcocks and grouse prohibited. Eggs and nests are proteoted. Wild ducks. geese and brants, September 1 to May 1. Nests and eggs of above pro tected equally. Trapping, snaring or netting of woodcooks, qualls and ruffed grouse forbidden, except on a man's own grounds. Possession by any person, or any express company, or carrier, during the close seneon is forbidden. Exportation of game prohibited. Shooting or being with gurs and dog without leave on the inclosed grounds of any individual or corporation where notices forbldding huntling are posted is a breaoh of law even in the open season. Shooting, hunting, or haviig flrearms in 
possession on Sunday in the open air is illegal. Song and inseotivorous birds and their nests protected. Restrictions placed upon certain parts of Housatunic River and flats, hunting belng prohibited except on Tues. days and Fridays between October 20 and April 20. Rails may be shot in New Haven, Fairfield and Litchfield counties from August 20 to January 1; other portions of the State from September 1 to January 1. Rabbits not protected. The use of ferrets for hunting rabblts prohibited. Trout, April 1 to July 1. Unlawful to sell trout less than six inches long. Fishirg in any other way than with hook andline, and within four hundred yards of any flshway, prohibited. Black bass, June 11 to May 1. Striped bass or salmon shall not be caught in seines or nets from June 20 to July 13, and striped bass must not weigh less than one-half ponnd. Shad, March 1 to June 20. Numerous local laws govern fishing ponds and streams. Netting ponds and lakes forbidden. A game and a fish warden in each county is appointed by the county commissioners.

DELAWARE.-Partridges, grnuse, qualls, rabbits and hares: in New Castle County, November 15 to January 1; In Kent and Sussex counties, November 15 to February 1. Reedbirds, ortolans and rails, September 1 to Fubruary 1. Geese, swans, brants and ducks, except Summer mer or woodducks, October 1 to April 15. Woodcocks, July 1 to September 15 and in New Castle County, November 15 to January 1, and in Kent and Sussex counties, November 15 to February 1. Non.residents must procure a license (fee \$25) from the Delaware Game Protective Association. Netting or snaring and night-hunting of partridges, grouse, woodcocks and quails, and trespass, and hunting game birds in snow prohibited. Hunting wildfowl with punt or swivel guns or with light prohibited. Insectivorous birds and their nests (except on one's own premises) protected. Muskrats, December 1 to March 30. Sunday hunting illegal. Shipment of game, except ducks and geese, out of a county or State without license is illegal, unless the shipper make oath that the game was legally killed and is not intended for sale or profit. Residents may shlp one dozen or less birds out of the State without a llcense. Black jass and trout, in New Castle County, June 1 to November 1; less than six inches in length protected.

DISTRICT OF COLUMBIA.-Partridges or quails, November 1 to February 1. Pheasants or ruffed grouse, August 1 to February 1. Woodcocks, July 1 to February 1. Prairie chickens, September 1 to February 1. Snipes and plovers, September 1 to May 1. Geese and ducks, September 1 to April 1. Reed birds and ortollans, September 1 to February 1. Deer, August 15 to January 1. Insectivorous birds protected, also nests and eggs. Trap or snare and swivel gun, Sunday shooting, night shooting, and trespass, prohibited. Fishing with hook and line, at any time. 
FLORIDA.-Deer may be killed, In each county, for four months of the year, sald four months to be designated by the respective county .mmiesioners, whose duty it is to publish same in some local newapa or post it. Quails, pertridges and turkeys, November 1 to March 1. Fire hunting, snaring and trapping prohibited

GEOKGIA.-Richmond County, deer, October 1 to January 1. Fawns protected. Wild turkeys and partridges (quails), October 15 to April 1. Summer duoks and doves, July 1 to April 1. Woodcocks, August 15 to January 1. Trapping and netting, poisoning, and destruction of nests of any game or insectivorous birds, prohibited. Dougherty, Randolph, Caphuun and Baker counties, deer and partridges (quails), October 1 to April 1. Llucoln and Baldwin counties, does and fawns, August 1 to Jan. uary 1; bucks, May 1 to September 1, and November 1 to March I. Wild turkeys and partridges (quails), Ostober 15 to March 15. Clarke, Fulton, Camden, Bartow, Floyd, Chatham and Whitfield counties, doer, partridges (qualls), wild turkeys, doves and wild ducks, October 1 to April 1, except Fulton County, where doves may be killed from August 1 to April 1. Many other county laws Fire-huntlng deer within the Btate prohibited, except on one's own premises, or with full consent of the owner of the lands hunted on. Sunday shooting prohibited. Fishing with hook and line permitted; traps, nets, weirs, etc., drugs, explosives, obstructions, etc., prohibited.

IDAHO.-Buffalos, elks, deer, antelopes and mountain sheep, Septem ber 1 to Jannary 1. Moose protected until 1897. Sage hens, pheasants, grouse and prairie chickens, July 15 to February 1. Geese and ducks, August 1 to Aprll 15. Nettlng of fish prohibited except in taking salmnn and sturgeon. No close season on fish.

ILLINOIS.-Deer and turkeys, September 1 to January 15. Plun ated grouse or prairie chlckens, September 15 to November 1. Rufied grouse or qualls, October 1 to December 1. Partridges or pheasants and qualls, October 1 to December 1 . Woodcocks, July 15 to September 15. Geese, brant ducks, or other waterfowl, September 15 to April 15. Gray, red, fox or black equirrels, June 1 to December 15. Possession and sale of game prohibited in close season, except game brought in from other States, which may be sold from October 1 to February 1 . The sale or exportation of quails, grouse, squirrels and turkeys killed within the state, prohibited. Doves and insectivorous birds and their nests protected. Bounty of two cents per head paid on English sparrows. Trapping, night hunting, swivel guns, shooting from sink bost, sallboat or steambost, and artificial blinds prohibited. Hunting or flshing within the enclosures of others without leave is a punishable misdemeanor. Obstructions in or across any stream so as to obstruct the tree passage of fish up, down or through such watercourse 
prohibited; the law prohibits the taking of fish with any device otlier than hook and line, except minnows for bait, within one-half mile of any dam ; prohibits the use of spears, acids medical and chemical compounds or explosives; prohibits flshing through the ice from December 1 to March 1. Three game wardens, to be appointed by the Governor.

INDIANA.-Deer, October 1 to January 1; chasing or worrying at any time and trapping prohibited. Qualls and pheasants (ruffed grouse), October 15 to December 20. Wild turkeys, November 1 to February 1. Prairio chickens, September 1 to February 1. Woodcocks, July 1 to January 1. Will ducks, September 1 to April 15. Squirrela, June 1 to December 20: Wild pigeons protected from any kind of molestation within a half mile of nesting. Insectivorous and song birds, their nests and eggs, except English sparrows, crows, hawks and other birds of prey, protected. Hunting with dogs or shooting on inclosed lands without written permission, forbidden. Any dog found rosming over the conntry unattended by owner or agent shall be deemed a run-about dog and may be legally killed. Sale, possession and transportation in close season prohibited; and tha transportation beyond the State at any time is forbiddeu. Gigging and spearing flsh allowed only from July 1 to January 1. Artificially stocked waters protected for three years after planting fish. Nets, seines, shooting, explosives and poisons prohibited. Hook and line fishing all wed at any time. Road supervisors are constituted officers of the law and are compelled by its provisions to enforce the same.

1NDIAN TERRITORY.-The Government prohibits every person, other than an Indian, from hunting or fishing.

IOWA.-Prairie chickens, September 1 to December 1. Woodcocks July 10 to January 1. Ruffed grouse or pheasants, quails and wild turreys, October 1 to January 1. Deer and elks. Septejuber 1 to January 1. Any wild duck, goose or brant, August 15 to May 1. Not more than twenty-five each of grouse, woodcocks or quails to be billed in any one day by any one person. Beavers, minks, otters and muskrats, November 1 to April 1 (for the protection of private property at any time). Trapping, snaring and netting of above birds forbidilen. The killing of pinnated grouse, woodcocks, quiails or ruffed grouse, for traffic, declared unlawful; and shipping or carrying them out of the State is forbidden. Not to exceed one dozen per day may be shipped to any person within the State. Use of awivel gun or poison prohibited. Bass, wall-eyed pike and cropples, May 15 to November 1. Salmou and tro'st, Apri 1 to November 1. Traps, nets, seines, trot lines, spears an 
obstructions of any kind, exploslves and polsonous drugs, prohibited. Transportation or sale during close sesson prohibited. Trespass and flshing in stocked waters forbidden. Hook and line fishing only permitted, except that a net not exceeding five yards in length may be used to catch minnows, and buffalo figh ana suckers only may be speared between November 1 and March 1.

KANSA8.-Prairie chickens or pinnated grouse, September 1 to Jinuary 1. Quails, November 1 to January 1. Snaring and trapping prohibited. Pursuing or hunting game of any kind on improved or occupied land, without consent of owner, prohibited. Unlawful to catci black bass, cropples, or wall-eyed pike except with rod, line and houk. All other fish, May 1 to July 1.

KENTUCKY.--Deer, males not-protected; females September 1 to March 1. Wildfowl, September 15 to May 1. Wild turkeys, September 1 to February 1 Woodcocks, June 1 to January 1. Quails and ruffed grouse, October 1 to March 1 . Doves, August 1 to February 1. Song and insectivorous birds, and nests of all birds, protected. Trapping, snaring and netting forbidden.

LOUISIANA.-Deer and ducks, October 1 to March 1. Turkeys, October 1 to April 15. Quails, partridges and pheasants, October 1 to April 1. Insectivorous birds protected. Nests and eggs protected. In the parish of Orleans, woodducks, July 1 to October 1. Deer, August 1 to March 1. Rabbits and hares, May 1 to August 1. Quails, October 1 to April 1. Night herons, July 1 to October 1. Marsh hens, Miay 1 to August 1. Slong birds protected, except grasses, larks, caille doves martins, papabottes and swallows. This is the general State law The police juries of the different parishes have the right to regulate the season in regard to deer, ducks, turkeys, quails, partridges and pheasants, and in many parishes they have done so. Where tise police juries do not regulate the time for their respective parishes, the general State law governs. Nets, seines, traps, weirs, etc., polsons, drugs, pollutlon of streams, or any obstruction to the free passage of fish, prohibited.

MAINE. - Moose, deer and caribou, October 1 to January 1. Deer, on the Island of Mt. Desert, November 1 to Janusry 1. The killing or having in possession, except alive, of more than one monse, two caribous and three deer is prohibited. Hounding illegal. Any person may law. fully kill any dog found hunting moose, deer or caribou. Mlnks, beavers, sables, ntters, fishers and muskrats, October 15 to May 1 . Wondducks, dusky ducks (black ducks), teals and gray ducks, September I to April 1. Ruffed grouse (partritlge) sand wondeocks, September 1 to December 1. Quails, October 1 to December 1. Pinnated grouse (prairie chickens), September 1 to January 1. Plovers, August 1 to May 1. Trapping, netting, snaring and killiug any wild duck or game blrd otherwiso than with a shoulder gun prohlblted. Insectivorons birds and their 
ueats prutected, excepting crows, English sparrows, hawks and owls. The Goverror may commlssion pérsous to take birds or nests for scientific purjoses, but the whole number holding commissions shall. not exceed ten at ay one time. A bounty of five dollars paid for every wolf and bear lilled in any town. Transportation and exportation of game prohbited, unless tagged and open to view. Shooting and hunting on Sunday prohibited. Back bass, July 1 to April 1; illegal to take at nny time from their spawning beds. No salmon, shad or otıer migratory fish shall be taken or fished for within five hundred yards of any fishway, dam or millrace, nor in the Penobscot River between the mouth. of the Kenduskeag Stream and the waterworks dam at Treat's Falls, on said river; nor between the Augusta highway bridge over the Kennebec River aud the Auguata dam, between April 1 and Noveinber 1, except with a single hook aud line, nor shall hook and line or artificial flies be used at any time within one hundred yards of any fishway, dam or millrace: provided that fly fizhing shall be allowed up to the bridge across Donny's River at Lincoln's Mill, but not between the said bridge and Lincoln's milldam. No salmon shall be killed or taken in any mauner betwden July 15 and April 1, except that between July 15 and September 15 salmon may be taken with a rod and single line. Alewives, April 1 to July 15; not allowed to be taken at any time in non-tidal or non-navigable waters by any net other than the ordinars hand dipnet. Snielts, in tidal waters, with hook and line only, Octbber 1 to April 1. Land-locked silmon, trout and togue, May 1 to October 1, except on the St. Croix River and its tributaries, and all the waters in Kennebec County, which is from May 1 to S sptember 15. White perch, July 1 to April 1. During February, March and April bona fide citizens of Malne may fish fur and take to their own homes land-locked salmon, trout and togue. Grapnels, spears, trawls, weirs, nets, scenes, traps, spoons, se t lines, or any device other than the single baited hook and line, or with artificial tlies, prohibited in all fresh water lakes, ponds and streams The taking of sea salmon or land-locked salmon less than nine inches in length, or trout less than five inches in length, prohibited. Not more than fifty pounds, at any one time, of land-locked salmon, trout or togue, in all, allowed to be transported by one person, and must be in possession of the owner. Dip-nets, with meshes smaller than one inch square in the clear, In any waters frequented by nigratory fishes except the St. Croix River, Octobar 1 to April 1. The prollution of stream; by offal of any kind prohibited. "Special laws govern the sea and shell fish industries ..... Special laws: Trout, land-locked salmon or other fish in the Misery and Saccatien or Socatian rivers which empty iuto Moosehead Lake, may be taken only from May 1 to September $10 . .$. . Trout and land-locke. 1 salmon in the Kennebag ?, Rangeley, Cupsuptic, Mooselucmaguntic, Mollychunkanumk and Welokeunebacock Lakes, or in streams flowing into or connecting said lakes, nay be taken nly from May 1 to February 1. The use of spawn as bait for flohlng in any of the foregoing 
waters duriug Scptember prohibited ......Trout or nd-locked salmon in the Rangeley Stream between the mouth of the Kennebago Strean. and the head of the island at the eddy, so.called; and in the South BCy Streain which emp:ies into Rangeley Lake, ab jve the dead water at tie mouth of said stream; and iu the Bemis Stream which empties jato Mooselucmaguntic Läke, above the blue water, at the mouth of said stream; and in the Cupsuptic Stream which empties into Cupsuptic Lake, between the first falls toward its mouth and its source, May 1 to :uly 1. Kennebago Stream between the foot of the first falls toward its mouth and the upper falls at the outlet of Kennebago Lake, May 1 to Soptember 1. That portinu of Rangeley Stream from the head of the islead at the eddy to the Rangeley Dam is protected at all times. Fish moy be taken only from May 1 to October 1 in the following ponds: Blue Mountaln, Tufts, Grindstone, Dutton, Beaver, Long Potter's and Four Ponds. Togue protected in Anonymous Pond untll 1895. 'Trout protected in Chase's Pond until 1894. Trout and pickerel protected in Great, Shorey's, Staples' and Parker's brooks until 1893. Kneeland Pond fisli protected until 1893. Pickerel may be taken with hook and line in Little Sebago Pond June 1 to October 1. Fish protected in Long and Weeks' Ponds and Woodsum's Brook until 1894. Nevers', Carsley, Rogers', Tingley and Lakin brooks protected until 1895. Perkins' and Nute brooks protected until 1892.

MARYLA ND.-Woodcocks, State law, June 15 to February 1. County laws: Anne Arundel, Caroline, Kent, Prince Georges, Queen Anne, July 4 to Febluary 1 ; Carroll, Montgomery. July 1 to January 1 ; Charles, Cecil, July 4 to February 4; Harford, June 10 to January 1; Talbot, July 4 to January 1 ; Wicomico, June 15 to February 1 ; Howard, June 15 to December 24. Rabbits, State law, October 15 to January 15. County laws: Allegheny, September 1 to January 1: Frederick, October 15 to January 1; Montgomery, September 1 to February 1 ; Cecll, Harford, November 1 to January 10 ; Worcester, November 1 to Jannary 15 ; Baltimore, November 1 to December 26 ; Dorchester, October 20 to February 1 : Howard, October 24 to December 24; Carroll, October 1 to December 24 ; Garrett, September 1 to December 1 : Washington, August 12 to January 1. Wild turkeys, county laws: Frederick, November 15 to Jannary 15 ; Garrett; September 15 to January 1. Qualls or partridges, State law, November 1 to December 24. County laws: Allegheny, Frederick, Talbot, October 15 to January 1; Queen Anne, October 15 tc? January 1; Baltimore, October 1 to December 26 ; Caroline, Worcester, Somerset, November 1 to February 1; Howard, October 24 to December 24 ; Cecll, Harford, November 1 to January 10; Carroll, October 20 to December 24 ; Montgomery, November $1 \cdot$ to December 15 ; Dorchester, October 20 to February 1 ; Washington, October 20 to January' 1 ; Wicomico, November 1 to January 1. Pheasants, Cecll, September 5 to February 1 ; Harford, 8eptember 1 to February 1; Howard, August 15 to December 24. 
Rall and reed birds: Cecil, September 5 to February 1: Harford, September 1 to February 1; Talbot, September 10 to .Tanuary 1 Squirrels, cunty laws: Carroll, September 1 to December 24; Wicomico, Septembur 1 to February 15. Plovers and sandpipers, county laws: Wicomico, Norember 1 to January 1. Wood and Summer ducks, county laws: Talbot ind Wicomico, September 10 to January 1. Minks, otters and muskrats, Wicomico County, December 15 to March 15. Deer, October 1 to January 1. Hounding prohibited. Speckled brook trout and speckled river trout, April 1 to August 15. Hook and line fishing only allowed. Sunday 4shing for trout prohibited. Use of swivel or big guns, and night shooting, prohibited. License necessary in Caroline, Charles, Dorchester. Howard, Anne Arundel and Baltimore counties. In all above cou nties exeept Caroline writteu permission from landowher is required in lieu of license and in Garrett County is absolutely necessary. Exportation of game is iorbidden from Montgomery, Worcester, Wicomico and Caroline counties. Many insectivorous birds are protected in Montgomery County.

MASSACHUSETTS.-Deer protected. Gray squirrels, hares and rabbits, September 1 to March 1. Ruffed grouse or partridges and woodcocks, September 15 to January 1. Quails, October 15 to January 1. Prai rie chickens or pinnated grquse protected. Ducks, all kinds, September 1 to April 15. Plovers, snipes, rails, sandpipers and other shore, marsh 'and beach birds, July 15 to May 1. Wild and passenger pigeons, gulls and terns, October 1 to May 1. Shooting at wildfowl and shore birds prohibited in the harbor and great ponds of Nantucket and the waters in and around the islands of Tuckernuck, Muskeget and the Gravelly Islund8. All wild and insectivorous birds not na med above, except English sparrows, crow blackbirds, crows, jays, birds of prey and wild geese, protected. Snaring, trapping, use of ferrets, battery, swivel or pivot guns, and torch or other artificial light prohibited. Black bass, July 1 to December 1. Trout, lake trout and land-locked salmon, April 1 to September 1; trout, in Berkshire, Hampshire and Franklin counties, April 1 to August 1. Hampden, April 1 to September 1. Salmon, May 1 to August 1. Smelts, June 1 to March 15. Black bass are not to be taken from Lake Cochituate, in the towns of Natick, Wayland and Framingham, Middlesex County. Trout and pickerel may be taken by line and hook only. Nets or seines with meshes less than five inches prohibited on the Connecticut River and its tributaries. Trespass, Sunday shooting and flshing, the pollution of streams, use of nets, seines, and exportation of game birds or animals, prohibited.

Mrchigan.-Deer in Upper Peninsula, September 25 to October 25; Lower Peninsula, November 5 to November 25. Killing deer or fawns in red or spotted coat, and in the water, or by means of pitfall or trap or artifleial light, forbidden. Hounding prohibited, and dogs found on a 
deer track may be kllled. Deer and elks protected on Bois Blanc Island until November 1, 1899. Wild turkeys, November 1 to December $1 \%$ Woodcocks, Augist 15 to December 15. (This is the new law, but it doss not take effect untill October 1, 1891, therefore the old law is in foce until then, which makes the open season on woodcocks commence september 1. The same is true regarding grouse, which, under the old law, may be legally killed from September 1 to October 1 and under the new law as stated herewith.) Lower Peninsula: Ruffed grouse (partrldge), pheasants, quails (Colins or Virginia partridg $\theta$ ), Norember 1 to December 15. Upper Peninsula: Ruffed grouse (partridge). October, 1 to January 1. Snipes and wild geese, red-heads, bluebills, carvas-backs widgeons and pintall ducks September 1 to May l. All othęr wildfowl, September 1 to January 1. Prairie chlckens protected to Norember, 1894. No trapping or snaring allowed. No punt or swivel guns aliowed. Nests and eggs of birds protected. Possession, sale or transportation during close season prohibited. Insectivorous and song birds protected. Expor. tation of game prohibited. Bounty of three cents per head paid on sparrows. Using guns within five miles of pigeon nestings and netting withln two miles is prohibited. Speckled trout, grayling, California trout, and landlocked salmou, with hook and line only. May I to September 1: less than six inches in length protected; also protected in streams where they are not native for three years after first planting: brook trout and graylings shall not be taken for sale or sold. Black, strawberry, green or white bass at any time, but by hook and line only: mascalonge, July 1 to March, 1. The use of dynamite, herculean or giant powder or other explosives, seines, pound nets, gill nets, or any species of nets, jacks or artlficial lights of any kind prohibited. There are local laws in several counties The Governor shall appoint a game and fish warden, to serve four years, and he in turn shall appoint deputy wardens-not to exceed three in each county.

MIINNESOTA - Deer and elks. November 1 to December 1. Moose, caribou and reindeer protected until April 20, 1896. Hounding prohibited. Woodcocks, July 4 to November l. Prairie chlckens, sharptailed grouse, ruffed grouse or pheasants, quails or partridges, septem. ber 1 to Novctuber 1. Geese, ducks, brants, snipe and all aquatic fowl, Auguet 20 to A pril 25. Minks, muskrate, otters and beavers, November 1 to Mas 1. All plumage, song and Insectivorous birds, their nests and eggs, and the nests and eggs of game birds protected, excepting blackbirds and sparrows. Trapping, netting, snaring, night hunting and the use of artificin lights, or other devices, prohibited, except that decoys may be used to lure ducks, wild geese and brants. Trespass prohlbited : lands must be posted. Speckled, rlver or brook trout, April 1 to October 1. Other flsh. May 1 to March 1, except where prohibited by local laws. Hook and line flshing only permitted. Nets, welrs, seines, explosiver, drugs, the pollution of streams, and fish houses on ice, prohibited. Flshing within fonr hundred feet of any fishway prohibited. 
AnsissIPPI -Deer. September 1 fo March 1.: Wild turkeys, ruffed grouse and quails, October 1 to May 1. Turtle doves and starlings, September 1 to March 1. Catbirds, mocking-birds and thrushes protected at ull times. In Tunica County, the killing or taking of any kind of game bird or animal, fowl or fish for profit, sale or transportation is prohibited until 1897. A land-owner may kill or fish on his own land, or give permission to others, but for immediate use only. Numerous co unty laws. In Tate County, open season for all kinds of game, November 1 to March 1. Pa nole County, quails, October 15 to April 15. The law grants the board of supervisors of any connty the right to change the State law, at any time. Selnes, nets, traps, explosives, drugs, etc., prohibited.

MISsódRI.-Deer, October 1 to January 1; turkeys, September 15 to March 1, Prairie chickens (pinnated grouse), August 15 to February 1. Ruffed grouse (comrhonly called pheasants) and quails (Virginia partridges), October 1 to January 1 . Woodcocks, July 1 to Jauuary 10. Waterfowl not protected. Doves, meadow larks and plovers, August 1 to February 1. All insectlvorous birds, their nests and egge, and those of game birds, protected. Possession of game out of season fllegal. Birds not showing shot marks to be considered as illegally killed. All railway companies, express companies and carriers are forbidden to carry game out of season. Nonresidents forbidden to trap or kill any deer, turkeys, prairie chickens, quails, ruffed grouse, wild geese, brants, wild ducks, snipes, woodcocks, and any furred animal. Shooting on inclosed lands without permission, illegal. Any person may catch or kill on his own premises, for his own or for his own family's consumption, quails or prairie chickens, from October 15 to February 1. Fishing with hook and line at auy time. Drugs," poisons, explosives, permanent obstructions, nets, weirs, geines, traps, etc., prohibited, except that a net may be used to catch minnows, and residents may take flsh with a seine or set net having meshes not smaller than two inches square from May 1 to April 1.

MONTANA.-Deer, antelopes, mountain sheep, mountain goats, elks and moose, September 15 to January 15. Buffalos and quails protected until 1901. Hunting for skins only, for market or for sale, and hounding prohibited. No close season for bears, curlews and snipes. Otters, martens and fishers, October 1 to April 1. Grouse of all kinds, sagehens, fool hens, pheasants and partridges, August 15 to November 15. Ducks and geese, August 15 to May 1. Song and insectivorous birls protected; their nests and eggs, and those of all game birds, protected. Hook and line and spear fishing allowed at any time, but catching speckled or mountain trout for profit prohibited; the use of explosives, yoisonous drugs and nets, traps, etc., prohibited. 
NEBKASKA.- Buffalos, elks, mountain sheep, deer and anteloper, October 1 to Jannary 1. Grouse, September 1 to January 1. Quails and turkeys, Octuber 1 to January 1. Snaring and trapping forbidden. Mirks and muskrats, February 15 to April 15. Ducks; geese and woodcocksnot protected. Nests and eggs protected. Sneak boats and punt and swivel guns prohibited. Insectivorous and song birds protected. Hornding of deer prohibited in Burt, Washington, Douylas, Sarpy, Cass, S6unders and Dodge counties. Transportation of grouse, quails, turkeys, buffalos, elks, mountain sheep, deer and antelopes prohibited at all times of the year. Fish can be taken with hook and line only. Fish planted by the Fish Commission or private persons protected at all times. Taking fish by auy other means than with hook and line prohibited.

NEVADA.-Deer, elks, antelopes, mountain sheep and goats, August 1 to Décember 1. Partriciges, pheasants, woodcnchs, geese, woodducks, teals, mallards and bther dncks, sandhill cranes, brants, swans, plovers, curlews, snipes, grouse, sharp-tailed grouse, robins, meadow-larks, September 1 to March 15. Sag 9 chickens, August 1 to January 1. Quails, September 1 to January 1. Beavers and otters protected until April, 1897. Insęctivorous birds and nests of all birds, protected. Unlawful to construct dams or any river obstruction without proper fishways. Brook trout and landlocked salmon, April 1 to October 1. Lake trout, April 1 to January 1. Fishing with hook and line only permitted. Pollution of streams, use of poisons, drugs, explosives, seines, traps, weirs, etc., prohibited. Trespassing prohibited. No close season for other fish.

NEW HAMPSHIRE.-DeGs, moose or caribou, September 1 to January 1. Hunting with dogs prohibited between September 15 and November 1. Not more than one moose, two caribou an 1 three deer permitted to be kllled by one person during the open season. Deer protected in Cheshire County until August 14, 1899. Mink, beavers, sables, otters or fishers, October 15 to April 1. Raccoons or gray squirrels, September 1 to January 1. Hares, rabbits or muskrats, September 1 tis April 1. Plovers, yellowlegs, sandpipers, ducks or rails, August 1 to Fobruary 1. Ruffed grouse, woodcocks and quails, September 1 to January 1. Insectivorous and song birds protected. Nest3 protected. Snaring or trapping ruffed grouse or quails prohibited. Transportation, possession or sale in close season prohlbited. Land-locked or fresh water salmon, April 15 to Septomber 30. Brook and speckled trout, April 15 to September 15. Pike-perch and white perch, July 1 to May 1. Black bass, June 15 to May 1. Mascalonge, pickerel, pike and grayling, June 1 to April 1; pickerel in Lake Warren, May 1 to November 1. Lobsters, September 15 to August 25. Brook trout less than five inches in length protected. In Sunapee Lake, brook, speckled, Loch Levin or rainbow trout of less than ten inches in length, and black bass less than eight inches in length protected. Not more than ten pounds of brook or speokled trout allowed 
In possession at one thme. Striped base, land-locked salmóč, aureolus of golden trout less than ten inches in length protected. Lamper eels, August 1 to May 1, under certain restrictlons. Flshing in certaln seatlons of Cockermouth River and Fowler's River prohibited until August 14; 1893. The use of nets, druge, explosives and sp saring, and the pollation of streams prohibited. The Governor appoints a fish and game commlieion, not exceeding thre in number, a ad game wardens are appointed for each town. Sunday shooting and trespass prohibited.

NEW JERSEY.-Ruffed grouse, October 1 to December 16. Qurils, November 1 to December 16. Woodcocks, October 1 to December 16, and during the month of July. Plovers, August 1 to December 16. Snipes, October 1 to December 16, and during the months of March and April. Prairle chickens, November 1 to January 1. Reed birds, rail birds and marsh hens, August 25 to Desember 16. Woodducks, September 1 to January 1. Gray and black squirrels, September 15 to December 16. Fox squirrels, September 1 to January.1. Rabbitg, November 1 to December 16. Song and insectivorous birds, and nests and eggs of all birds protected. Trapping and snaring prohibited. Salmon trout, March 1 to October 1. Brook trout, April 1 to July 15. Black and Oswego, bass, May 30 to 'December 1. Pickerel and pike, May 1 to March 1. Set lines, nets, seines, or any device obstructing the free passage of fish prohibited. Non-residents must comply with the by-laws of the game protective societies of the State or be debarred from shooting under penaity,

NEW MEXIO0.-Elks, buffalos, deer, fawns, antelopes, mountain sheep, wild turkers, grouse and quails, September 1 to May 1 Not applicable to travelers or persons in camp, whose necessities may compel them to kill for purposes of subsistence. Trout or other foolifishes for subsistence only and with hook and line only, June 1 to November 1. The use qf poisons, drugs, explosives, nets or aimilar devices, artildial obstructions and pollution of stres ms, forbidden.

NEW YORK.-Deer, August 15 to November 1; hounding permitted, from September 1 to October 20, except in Queens and 'Suffolk countles where it is lawful only the first ten days of October, exclusive of Sundays; in St. Lawrence and Delaware counties hounding is prohibited at all times; moose and fawns protected. But three deer can be taken in one season. and one only may be transported when accompanied by the owner. Crusting and yarding of deer prohlblted. Ducks, geese and brants, September 1 to May 1 ; in the waters of Long Island, October 1 to May 1; in Chautauqua Oounty, September 1 to February 1. Night hunting.and use of artificial light, punt or swivel gun and nets prohibited. Use of floating batteries, etc., prohibited; and baugh houses and decoys must be within twenty rods from the shore, except in Great South Bay west of Smith's Polnt, Peconic Bay, Shennecock Bay, Lake Ontario, 
RAver Șt. Lawrrouce and the Hudson River below Albany. Shooting fron sall or steam boats prohiblted, except on Long Island Sound, Gardner's and Peconic Bays, Lake Ontario and Hudson River below Iona Ieland. Qualls, November 1 to January 1. On Robins Island, October 15 to February 1. Rabbits and hares, November 1 to February 1. Huntily with ferrets prohibited. Woodcocks, ruffed grouse and prairie chickens, September 1 to January 1. Snipes, sandpipers and plovers, July 10 to January 1 in counties of Queens and suffolk. Rail birds, and meadow hens. In counties of Queens and Suffulk, September 1 to January 1. Netting and sñaring prohibited. Squirrels, August 1 to February 1; in Cortland County, September 1 to January 1. Song und insectivorous birds protected. Nests protected. Robins and blackblrds may be shot on Long Island and Staten Island from November 1 to January 1. English sparrows, crows, blackbirds, hawks and owls notprotector. Speckled, brook, California and brown trout, April 1 to September 1; in Forest Preserve, May 1 to September 15: Steuben County, May 1 to August 1. If less than six inches in length must be returned to waters where caught. Lake trout, salmon trout and land-loc'sed salmon same as speckled trout, except in Forest Preserve, May 1 to October 1; and iu inland waters, April 1 to Oetober 1 ; Lake George, May 1 to October 1 . Sa'mon, March 1 to August 15, with hook an 1 line, angling by hand only. Black bass, May 50 to January 1, except in Oneida Lake, June 1 to March 1; and Lake Mahopac, Schroon Lake and River, Paradox Lake, Friends' Lake, Skaneateles Lake, Lake Erie and Niagara River above the falls, July 1 to January 1 ; Lake George and Brant Lake, August 1 to January 1 ; St. Lawrence, Clyde, Seneca and Oswego rivers, lakes Ontario, Conesus and Black, May 20 to January 1 ; Lake Champlaln, June 15 to January 1 ; Glen Lake, July 10 to January 1. All black bass weighing less than one-half pound or less than eight inches in length protected; this restriction applies also to Oswego bass caught in GHen Lake and fresh water striped bass. Mascalonge and plke-perch, May 30 to January 1 ; St. Lawrence, Clyde, Seneca aud Oswego rivers, lakes Ontario, Conesus and Black, May 20 to January 1 ; Oneida Lake, May 30 to March 1 ; Lake Champlain, June 15 to January 1; Erie County, July 1 to January 1. Oswego bass, same as mascalonge, except in Glen Lake, July 10 to January 1. Fresh water striped bass, May. 20 to January 1; Erie County, July 1 to January 1. Balt water striped bass, no close season; protected in Jamaica Bay under six inches in length; in other waters size same as black bass. Sea bass and tautogs under six inches in lenzth protected in Jamaica Bay. Pike, Lake Champlain, June 15 to January 1. Pickerel, Lake George and Glen Lake, July 1 to February 15 ; Lake Champlain, June 15 to January 1. Shad, Hudson River, March 15 to June 15 ; none allowed to be taken above the northern line of Westcliester County from sunset on Saturday to sunrise on the following Monday. Bullheads, Lake George and Glen Lake, July 1 to April 1. The Forset Preserve includes portions of the counties of Clinton, Delaware, Essex, Franklin, Fulton, Hamil - 
won, Herkimer, Lewis, Oneida, St. Lawrence, Saratoga, Warren, Washipgton, Greene, Ulster and Sullivan. The State is divided into fifteen game and fish protection districts. Protectors appointed for each district.

NORTH CAROLINA.-A new law has been passed, regulating the open season in the several counties of the State. We have not received a copy of it up to the time of going to press, Jbut will publish a synopsis of it in s subsequent issue.

NORTB DAKOTA.-Buffalos, elks, deer, antelopes and mountain sheep, September 1 to January 1. Grouse of all kinds, September 1 to January 1. Ducks, snipes, geese, brants, plovers and curlews, September 1 to May 1. Not more than twenty-five of any of the game birds or fowl mentioned allowed to be killed or had in possession at any one time. Their nests and eggs protected. Exportation of game prohibited; not more than one dozen of either of said birds allowed to be shipped or transported in any one day within the State by any one person, after making affidavit that said birds have been legally killed. Shoulder guns on!y allowed; all other devices, poisons, traps, etc., prohibited. Wasting game or leaving the same lying about, prohibited. Pike, pickerel, perch, base, mascalonge, May 1 to February 1. Fishing with hook and line oniy allowed: all other devices prohibited.

OH10.-Deer, Ootober 15 to November 20. Quails, November 10 to December 15. Squirrels, July 1 to December 15. Woodcocks, July 15 to November 1. Buffed grouse or pheasants and prairie chickens, September 1 to December 15. Ducks, September 1 to April 10. Turkeys, October 1 to December 15. Trapping or snaring quails or partridges prohibited. The use of any other gun than a shoulder gun, artificial light, sink boat or battery, steam or naphtha launch, net or trap, prohibited. Nests and eggs of all game birds and fowl protected. Ducks shall not be hunted on Sunday, Monday and Tuesday of any week between September 1 and April 10. Sunday hunting prohibited at all times. Swans, insectivorous birds and their nests protected at all times. Disturbing pigeon roosts or discharging any firearm at any wild pigeon within one-half mile of a wild pigeon roost, prohibited. The use of ferrets for catching rabbits on the premises of another, prohibited. Muskrats, minks, and otters, March 1 to April 15. Brook trout, salmon, land-locked salmon, or Callfornia salmon, March 14 to Septeraber 15 . With these exceptions there are no restrictions to fishing with book and line, with bait or lure, except that bass ander eight inches in length, and fish in private or posted waters.are protected. Netting and seining are allowed in many waters subject to specific or local laws. Explosives, poisonons drugs, spearing, shooting, trespassing, and selling or having in possession any. kind of fish in close season, prohibited. Spearing suckers is allowed in all streams flowing into Lake Erie. 
OREGON.-Male deer or buck, July 1 to November 1 ; female deor or doe, Angrist 1 to January 1; spotted fawns protected; neither male nor female deer can be kllled at any time for other than food purposes. Elks, moose and mounteln sheep, August 1 to November 1 ; shall not be kllled for other than food purposes; wilds swans and ducks, September 1 to March 1; ducks can be killed at a y time to protect growing crops : grouse, pheasents. mongolian pheasants, quails or partridges, September 1 to November 15; netting and snaring quails, prairie chickens and ruffed grouse, or having the same in possession alive, prohibited; nests and eggs of game birds and wildfowl protected. Ring-negk Mongolian pheasants, Tragopan pheasants, sllver pheasants and golden pheasants protected. Mountain or brook trout, April 1 to November 1. Redflsh and lake trout, January 1 to August 10. Salmon protected in the Columbla River during March, August, September and during the weekly close times in April, May, June and July, i..e., from 6 p. m. Seturday to 6 p. m. Sunday; taking them with any other device than hook and line prohlbited in any other waters, April 1 to November 15. Fishing near flshways, drugs, explosives, nets, pollution of streams, etc., and trespass, prohibited.

PENNSYbVania. - Eliss and deer October 1 to December 15; but ow Ing to an error, it is illegal to have deer in possession after November 30 The killing of fawns when in spotted coat, chasing of elks or deer with hounds, and the killing of deer when in the water prohibited. Squirrels, September 1 to January 1. Hares or rabbits, November 1 to January 1. Hunting or killing of rabbits with ferrets prohibited. Wild turkeys, October 15 to January 1 . Plovers, July 15 to January 1. Wood cocks, July 4 to January 1. Quails, November 1 to December 15. Ruffed and pinnated grouse, October 1 to January 1. Rails or reed birds, September 1 to December 1. Wildfowl, September 1 to May 1. Insectivorous birds protected, except English sparrows. Pigeon nestings protected against firearms to a radius of one-fourth mile from roosting or breeding place, and penalty for disturbance in anymanner while nesting; end snaring or netting for the purpose of killing during the nesting season prohibited. Snaring, netting or catching of game birds by torchlight prohibited. Sunday hunting and shooting prohibited Shooting of wildfowl limited to use of shoulder gun only. Ses salmon, April 1 to July 1. Speckled trout. April 15 to July 15; under fire inches in length protected. Lake trout, Juuuary 1 to October 1 . Black, green, yellow, willow, rock, Lake Erie and grass bass, pike, pickerel, and wall ; $^{\text {; }}$ eyed pike or Susquehanna salmon, June 1 to January 1. Bass less than six inches in length protected. Germen carp, September 1 to May 1. Artificially stocted streams protected for three years after stocking. Hook and line fishing only allowed; use of nets ar traps of any kind, poisons eto. probibited. 
RHODE ISLAND.-Woodcocks, ruffed grouse or partridges, September 1 to January 1. Quails, October 1 to January i. Bartram's tattlers or grass plovers, Angust 1 to April 1. Dusky or black ducks, wood or Summer ducks, and blue or green-winged teals, September 1 to March 1, grouse or heath-hen, November 1 to Jauuery 1. Trapping prohibited, and shoulder guns only allowed. Squirrels, rabbits and hares, September 1 to January 1; nce of ferrots or weasels to catch rabbits or hares forbidden. Wild pigeons, Auguet 10 to January 1. Eggs and nests protected. All fresh water ducks other than those belore mentioned, all sea ducks, geese, crows, kingfishers, crow blackbirds, herons, bitterns, plovers (except as mentioned above), curlews, ralls, sandpipers, snipes and all birds of prey except fish-hawks, or ospreys, may be killed at any time. Trout, March 1 to Auguet 15; less than six inches in length pretected at all times. Black bass protected until 1893; after that, July 15 to March 1 . Hook and line flishing only allowed

sOUTH CAROLINA.-Deer, September 1 to February 1, except in the countiea of Clarendon Georgetown, Colleton, Williamsburg, Marlboro, Kershaw, Harry, Darlington, Marion and Berkeley, where it is August 1 to February 1. Wild turkeys, ruffed grouse, woodcocks and quails or partridges, November 1 to April 1. Doves, August 1 to Msrch 1. Insectivorous birds protected. Fire-hunting prohibited. Non-residents

SOUTH DAKOTA.-Prairie chickens, ruffed and sharp-tailed grouse, August 15 to January 1. Snipes, plovers, curlews and waterfowl, Sep. ¿amber 1 to May 15. Quails protected until February 3,1893. Song and insectivorous birds protected. Netting and trapping prohibited. Shooting of more than twenty-five birds of one kind in a day or the possession of the same prohlbited. Shipping out of State, and the shipment of more than twelve birds within the State, prohibited. Deer, buffalos, elks, antelopes and mountain sheep, September 1 to January 1. In the counties of Clay, Union and Lincolu, deer from October 1 to January 1. Bass, mascalonge, pike, pickerel and perch, May 1 to February 1. Those intended for breeding may. be taken at any time. Netting prohibited except in the Missouri and Red rivers. Shipment out of the State of carcass of buffalo, elk, deer, antelope or mountain sheep prohibited.

TENNESSEE. - In counties of Anderson, Cheatham, Coffe $\theta$, Davidson, Dickson, Fayette, Fentress, Giles, Grundy, Hamblen, Hamilton, Hancook, Hardeman, Hay wood, Henry, Houston, Jefferson, Knox, Lake, Lincoln, London, McMinn, Madison, Monroe, Montgomery, Oblon, Roane, Rutherford, Sevier, Shelby, Stewart, Sullivan, Sumner, Tlpton, Trousdale, Unicol, Williamson and Wilson, unlawful to kill or hunt deer for profit, except that citizens may kill deer for profit on their own landefrom Anguat 1 to January 1, and during that period may hunt or kill deer for 
their own consumption. Unlawful in these counties for any person to hunt, net, trap or capture any quall or partridge except from November 1 to March 1, and not then for proft, exoept that, during that season, a citizen may do so for proft on his own land but not elsewhere. Netting qualls at any season by any person prohibited in sald countios. In counties of Scott, Fentress, Pickett, Morgan, Cumberland, Bledsoe, Sequatchle, Van Buren, White, Putnam, Rhea, Clay, Campbell, Henry. Johnson, Carter, Sullivan, Melgs, Claiborne, Grundy, James, Overton, Marion, Roane, and Warren unlawful for non-residents to hunt, kill, catch or capture any species of game or fish, and unlawful for any person to hunt or kill any species of game for profit. Morgan County, deer and wlld turkeys, October 1 to December 1. Benton and Humphreys counties, deer, September 1 to Jantuary 1. Dyer, Maury, and Bedford counties, deer, September 1 to March 1. Pheasants, grouse, quails, partridges, larks, woodcocks, and snipes, September 15 to March 1; wild turkeys, Aeptember 15 to May 1; song and insectivorons birds and nests protected. Unlawful to trap or net geme. Robertson and Maury counties, wlld turkeys, partridges, qualls, grouse, pheasants, woodcocks, snipes and lerks, September 1 to February 1. Shelby County, squirrels, september 1 to February 1 ; nests and eggs protected. Montgomery and Cheatham counties, grouse or pheasants and larks, October 15 to March 1; woodcocks, doves and wild turkeys, August 1 to March 1 ; snipes, plovers or ducks, September 1 to May 1. Johnson, Carter, Washington, Greene and Marion counties, partridges, quails, woodcocks, pheasants and wild turkeys, October 1 to April 1: Unicoi, Hamilton, Henry and Haywood counties, woodcocks, pheasants and wild turkeys, October 1 to Aprll 1; unlawful to export game mentioned from these counties beyond the limits of the State; this does not apply to persons killing game on their own premises. Johnsion and Carter counties, deer protected. Bedford County, partridges may be trapped or netted September 15 to March 1; wild turkeys may be trapped september 15 to May 1 . The use of dynamite, glant powder, explosive or auy other substance, other than angling with hook and line prohibited. Use of hand or minnow net for taking small flah or minnows for bait allowed.

TExAS.-Deer, June 1 to December 1. Wild turkeys, September 1 to May 15. Prairle chickens, August 1 to March 1. Quails and partridges, October 1 to April 1. Song and insectivorous birds protected. No seining, trapping or netting of fish permitted above tidewater from February 1 to July 1. Use of nets or seins with meshes less than two and one. half inches square, drugs, explosives and poisons, prohibited. Owing to thelr being too thinly settled or unorganized, these provisions do not apply to the countles of Anderson, Andrews, Angelina, Archer, Armstrong Atascosa, Balley, Baylor, Bell. Borden, Bosque, Brazos, Briscoe, Brown, Callahan, Cameron, Camp, Carson, Cass, Castro, Cherokee, Childres, Clay. Cochran, Collin, Collingsworth, Comanche, Cooke, Coryell, Cottle, Crosby, 
Dallam, Dawson, Deấ Smith, Delta, Dickens, Dimmitt, Donley, Easland, Ellis, Erath, Fisher, Floyd, Franklin, Freestone, Frlo, Gaines, 'Garza, Gonzales, Grax", Greer, Gaudalupe, Grimes, Hale, Hall, Hamilton, Bansford, Hardeman, Hartley, Hiaskell, Hemphill, Hockley, Hood, Hopkins, Howard, Hunt, Hutchinson, Jack, Jackson, Jones, Karnes, Kent, King, Kınney, Knox, Lamb, Lipscomb, Lubbock, Lynn, Martin, Maverick, Mitchell, Montague, Montgomery, Moore, Morris, Motley, Nacogdoches, Nolan, Ochiltree, Oldham, Palo Pinto, Parmer, Polk, Potter, Ralns, Randall, Robert, Robertson Rockwall, Runnells, Sabine, San Augustine, San Jacinto, Scurry, Shackleford, Shelby, Sherman, Smlth, Bomervell, Stephens, Stonewall, Swisher, Taylor, Terry, Throokmorton, Titus, Upshur, Van Zandt, Walker, Wheeler, Wichita. Wilbarger, Wilson, Wise, Wood, Young, Yoskum, Zavalla. Houston protects Quails, only, as above. Fannin County proteots prairie chickens, quails and insectivorous birds, as above. Lee and Fayette protect turkeys, prairle chickens and quails, as above. Bastrop and Brazoria protect deer, turkeys, pral. rie chickens and quails, is above. Kaufman protects quails and insectivorous birds, as above. Bowie protects deer and turkejs, as above.

UTAH.-Elks, deer, buffalos or bisons, antelopes and mountain sheep, September 1 to December 1. Hounding prohibited; dogs in pursuit of above animals may be legally killed. Hide and skin hunting, the exportation of $\mathrm{g}$ ame animals or fish, or $\mathrm{h}$ aving in possession during the close season, prohibited. Quails, partridges, pheasants, prairie chickens and sage-hens or grouse, August 15 to March 15 . Wild geese, ducks and snlpes, September 1 to April 1. Night hunting and trapping prohibited. Insectivorous birds, the English sparrow and blackbird excepted, protected. Nests protected. Trout, June 15 to February 15. Trout less than six inches in length protected. Imported fish protected. Seining, with lawful slze meshes, in Bear and Utah Lakes, October 1 to March 1; in Greэn River at any time. The use of set llnes, nets, seines, welrs, dams or other artiflcial obstructions, poisons, drugs and explosives of any kind, prohibited. Indians are not exempt from the laws except on their reservations.

VERMONT.-Gray squirrels, September 1 to February 1. Quails and ruffed grouse, September 1 to February 1. Hunttng ruffed grouse with dogs prohibited. Woodcocks, August 15 to February 1. Wildfowl, September 1 to February 1, except woodducks. Nests and eggs, protocted, and trapping and snaring forbidden. Insectivorous birds, eggs and nests protected. Sunday shooting prohibited. Deer protected until 1900. Minks, besvers, fisners and otters, November 1 to April 1. Trout, land-locked salmon, salmon trout or longe, May 1 to September 1. Trout, land-locked salmon and salmon trout less than six inches in length, protected. Black bass, June 1 to February 1. Black biss less than ten inches in length, protected. Whitefish or lake shad, November 15 to 
November 1. Wall-eyed pike, pike-perch, June i to February 1. Fishing allowed with hook and line only All other devices prohibited. Lociil laws govern many waters.

VIRGINlA - The game and tish laws uf Virsuid are so complicated that it is almost impossible to conpile an intelligible synopsis of them, the State law not being in force in the mfjorlty of cuunties owing to local enactments. A license in writing must be obtained from the owner or tenant of any land or watercourse. Non-residents prohibited from killing any wildfowl below the head of tidewater. Night shooting and shooting from skiffs, floats or sink boxes prohibited Deer, August 15 to January 1; Essex County, August 15 to February 1; Frederick and Shenandoah counties, September 15 to Deceinber 15; King and Queen counties, August 15 to February 1; King William County October 1 to:February 1: Lancaster and Richmond counties, October 15 to February 1. Protected in Page County; Rockingham County, Uctober 1 to November 15. Hounding prohibited by State and connty laws, with slight exceptions. Pheasants or ruffed grouse and turkers, Sepember 15 to February 1, in the counties west of the Blue Ridge (except Rockbridge), and in Rockbridge and counties east of the Blue Ridge (except Prince Edward), October 15 to January 15; Prince Edward Eounty, October 15 to March 1. Turkeys, Frederick and Shenandoah counties, November 1 to February 1; Isle of Wight, Nansemond and Southampton counties, September 15 to February 15: King and Queen counties, August 15 to February 1; King WillIam County, November 1 to March 15. Wild fowl (except Summer ducks), September 15 to May 1. Woodcocks, November 1 to April 1; Frederick and Shenandoah counties, July 1 to April 1; Alexandria and Fairfax counties, July 4 to January 1: Loudon County, June 15 to January 1. Partridges or quals in the following "counties as noted herewith: From October 15 to January 15: Albemarle, Alexandria, Bucklugham, Buchanan, Campbell, Charles City, Charlotte, Chesterfield, Culpeper,Elizabeth City, Fairfax, Fauquier, Fluvanna, Gloucester, Goochland Greene, James City, King George, King Willam, Louisa, Madison, Matthews, Middlesex, Nelson, New Kent, Northumberland, Orange, Patrick, Pittsylvania, Powhatan, Prince George, Prince William, Rappahannock, Spotsylvania, Stafford, Surry, Warwick, Westmorelaud, York. From October 15 to January 1: Bland, Botetourt, Car roll, Craig, Dickinson, Floyd, Giles, Lee, Loudon, Montgomery, Page, Pulaski, Roanoke, Russell, Rockingham, Tazewell, Wise, Warren. Froin October 15 to March 1: Prince Eilward. From October 15 to February 1: Lancaster, Richmond. From October 15 to February 15: Halifax, Hanover Henrico, King and Queen. From October 31 to Decomber 25: Clarke. From November 1 to January 1: Frederick, Shenandoah. From November 1 to February 16: Henry, Nansemond, Isle of Wight, Southampton. From November 1 to March 1: King William. From November 1 to 
February 1: Accomac, Alleghany, Amherst, Augusta, Bath, Bedford, Caroline, Essex, Franklin, Grayson, Highland, Northampton, Norfolk, Rockbridge, Scott, Smyth, Washington. Wythe. From November 15 to February 15: Princess Anne. The counties of Amelia, Appomattox, Brunswick, Cumberland, Dinwiddie, Greensville, Lunenburg, Mecklenburg, Nottoway and Sussex, have no law on the subject. Mountaiu trout, April 1 to September 15. Bass of any kind, July 1 to May 15. Hook and line fishing only allowed. Nets, traps, weirs, obstructions to free passage of fish, drugs, poisons, pollution of stı eams, etc., prohlbited. Local laws regulate fishing in the proxinity $e^{\prime}$ dams, junctions, mill ponds, etc.

WASHINGTON.-Deer, moose, elks, mountain sheep and mountain̄ goats, for food purposes only, August 15 to January 1. Hide and head ' hunting prohlbited. Hounding elks or moose except during October, November and December, prohibited. Hounding deer prohibited at all times. Swans and wild ducks of any kind, August 15 to April 1. Pralrie chickens, mountain grouse, blue grouse, pintail gronse, pheasants and sayehens, August 1 to January 1. California and Bob White qualls, October 1 to January 15. Trappipg and snaring prohibited. Nests and eggs of all game birds and fowl protected at all times. Night hunting prohibited. Shooting with swivel or pivot guns, or from sink boxes, rafts, sneak boats, or other devices, except from shore blinds or over decoys, prohibited. Brook trout, mountain trout, bull trout and salmon trout, May 1 to November 1; with hook and line only. Fishing for salmon within one mile below any obstruction erected to obtain fish for propagation, or use of nets, weirs, вөinem, traps or other simllar devices, drugs, explosives, etc., prohibited. Trespass prohibited; lands and waters must be posted. Fish planted in waters protected for three years after planting. Salmon, in Columbia River and tributaries, April 10 to August 10 and September 10 to March 1; protected at all times between 6 p. m. Saturday and 6 p. m. following Sunday. Gray's Harbor, Shoalwater Bay and trlbutaries, December 15 to November 15. Puget Bound, June 1 to March 1. Pollution of streams prohibited, and dams must have fishways. From and after January 1, 1892, forelgners and non-residents prohibited from taking for sale or profit any salmon, sturgeon or other fool fish. Fish commissioner appointed, with salary of $\$ 2,000$ and expensies. Game warden and deputies appointed by the Governor.

WEST VIRGINIA.-Quails, November 1 to December 20. Wild turkejys, September 15 to January 1. Ruffed and plnasted grouse, November 1 to January 1. Snipes, March 1 to July 1 . Woodcocks, July 1 to geptember 15. Wild ducks, geese and brants, October 1 to April 1. Deer, September 15 to December 15. Insectivorous and song birds, their nests, and eggs, and those of game birds and waterfowl, protected. Snaring, netting or trapping, and the use of swivel or pivot guns, or sneak or push 
boats, forbidden. Hounding deer prohibited until June, 1892. Tŕout 'and land-locked salmon, January 1 to September 1 . Jack salmon or white salmon, June 15 to April 1. Nets, weirs, traps, obstructions, poisons, drugs, explosives and trespass, prohibited.

WISCONSIN.-Woodcocks, quails (except in Waiworth, Rock, Jefferson, Waukesha, Milwaukee, and Racine counties, where quails, their nests and eggs are protected until Septemb r 1, 1894), partridges, pheasante or ruffed grouse, prairie chickens, sharp-tailed grouse, or grouse of any other variety, snipe; plovers, mallard, teal or wood ducks, September 1 to December 1. Wild ducks of any other variety, wild geese or brants of any variety, or any aquatle fowls whatever, September 1 to May 1. Hunting quails or any klnd of grouse(partridge, pheasant, or prairle chicken ) with dogs prohibited until Sertember 1, 1893. Squirrels, August 1 to December 1. Deer, November 1 to Decemb 3 r 1 . Hounding or worrying deer prohibited at all times. Snaring, netting, trapping, spring guns, plvot guns, swivel guns, or any similar coutrivance, or any firearm other than a shoulder gun, prohibited. Sneak boats, scull boats, sailboats, steamboats or floating rafts or boxes, or any similar device; of any blinds in open water outside the natural growth of grass or rushes, probibited. Otters, martens, and fishes, November I to Msy 1. The use of dogs or ferrets, nets, traps, snares, clubs or sticks, in the taking or killing of hares or rabbits, prohib:ted. Eggs and nests of wild pigeons, game and song and injectivurous birds protected. Pigeons protected within three miles of theif roost. English sparrows not protected. Brook, rainbow and mountain trout, April 15 to Septembэr 1. Mackinaw (lake) trout, January 15 to October 1. Pike (wall-eyed), May 1 to March 1. Black, green and Oswego bass, and mascalonge, May 1 to February 1. Hook and line only. Whilefish may be taken in inland waters with a dipnet having a hoop not exceeding thirty inches in diameter fobm November 10 to December 15. With this exception the use of any gill, fyke, pound, seine, dip or other net or snare is prohibited in the inland lakes, rivers or streams of the State. Minnows, shiners, chubs, dace, suckers or stickle-backs may be caught for bait in quantities not exceeding onehalf bushel in measure, at any one time, by méans of a dip-net or seine, except in streams or waters inhabited by or containing trout of any variety. No such fish caught for balt allowed to be shipped out of thy State. The use of dynamite or other explosives, and the pollution waters with sawdust, fish offal, etc., prohibited. Spearing prohibited, except in the warjors of the Mississippi River and sloughs, Lake Winnebago, Fox and Wolf rivers, and all waters emptying lato Green Bay, where sturgeons and píckerel only may bespeared. Catching brook, rainbow or mountain trout for sale, out of public waters, is prohibited. The sale of any wall-ejed pike, black bass and frog bass, of less than one pound each, prohibited. It is unlawful for any person to have in his possession to exceed ten pounds of wall-eyed pike, black bass or frog bass weighing 
less than one pound each. Entering ou posted preservez without conseut of owner is trespass. Local laws are in force in many counties. A paid State game and flsh warden, to hold office for two years, is appointeil by the Governor. He may appoint as many deputies as he desires, thc latter to receive constable's fees for performance of duty.

WYOMING.-Partridges, pheasants, prairie chickens, prairie hens or grouse, Augu st 15 to November 1. Sage chickeas, July 15 to September 15. Snipes, green shanks, tatlers, godwits, curlews, avocets, or other waders, plovers, quails, larks, whip-poor-wills, finches, thrushes, snow . birds, turkeys, buzzards, robins or other insectivorous birds, protected at all times. Wild ducks, August 1 to May 1. Deer, elks, moose, mountain sheep, inountain goats, antelopes, protected at all times, except that a bona fide resident may at any time kill not more than three of any of said animals in any one week, for the purpose only of supplying himself and family with food. Non-residents prohibited from hunting them at any time. Bison or buffalos and beavers protected until March 15, 1900. Exportation of game, hides or heads prohibited. Any game brought into the State must be accompanied by an affidavit, to be recorded in the office of the county clerk and recorder of the county, to prove that said game was not killed in any other State or Territory in violation of the laws of such State or Territory. Trapping and netting prohibited. Justices of the peace are empowered to appoint special gam 


\section{BLITISII YOSSESSJONS.}

QUEBEC.-Moose and caribou, September 1 to February 1. Deer, vetober 1 to January 1. Hounding, snaring and trapping prohtuited. Unless a special permit is first obtaned from the Commissioner of Crown Lands, no person (Indian not exempted) shall kill more than two moose three saribous and four deer during the hunting season. After the first tell days of the close season transportation of any game prohibited. Beavers, minks, otters, martens and pekans, November 1 to April 1, Muskrats, in counties of Maskinonge, Yamaska, Richẹlien and Berthier, A pril 1 to $\mathbf{M}$ y 1 . Hares, November 1 to February 1. Woodcocks, snipes and partrid ges, September 1 to February 1. Ducks of all kinds, Septernber 1 to $\mathrm{Mag}_{1} 1$. Other birds, except eagles, falcons, hawks, wild pigeons, kingfishers, crows, ravens, waxwings, shrikes, jays, magpies, sparrows and starlings, September 1 to March 1. Guns of larger than 8-bore prohibited. Snaring and trapping, except of partridges, prohibited. Night hunting and exportation of game prohibited. Nests and eggs'protected. A license required for persons not residents of Quebec or Ontario to hnnt or fish. Salmon, February 1 to August 15. Ouananiche, December 1 tn September 15 Speckled trout, January 1 t) Ostober 1. Gray trout and lunge, December 1 to October 15. Pickerel, May 15 to April 15. Bass and mascalonge, June 15 to April 15. Whitefish, Deoember 1 to November 10. Fishing with hook and line only permitted.

ONTARIO.-Deer, October 15 to November 20. Moose, elks. reindeer or caribous entirely protected until October 15, 1895. Prior to 1895 no person not a resident of Ontario or Quebec for three months shall at any time kill or hunt deer, elks, moose, reindeer or caribous; nelther shall any persun kill more than five deer in one year, hunting parties of two not more than eight, and hunting parties of three or more not more than twelve. Grouce, pheasants, prairie fowls and partridges, Fiptember 1 to January 1. Quails and turkeys, October 15 to December 15 . Woodcocks, August 15 to January 1. Snipes, rails and plovers, September 1 to January 1. Ducks, Septeniber 1 to January 1. Swans and geese, September 1 to May 1. Hares, September 1 to March 15. Quails cannot be sold, bought or bartered for in any way. Beavers, minks, muskrats, martens, raccoons, otters or fishers, November 1 to May 1. Trapping, snaring, swivel guns, poisoned baits, etc., night shooting, and trespass, prohibited. Insectivorous birds, their nests and eggs, and those of all game birds, protected. Salmon, trout and whitefish, December 1 to November 1. Fresh water herring. December 1 to October 15. Speckled, river and brook trout, May 1 to Septernber 15. Bass and mascalonge. 
June 15 to April 15. Pickerel (dore), May 15 to April 15. Use of nets, explosives, spears or grapple hooks prohibited.

MANITOBA. -Ail kinds of deer, including cabri or sntelopes, elks or wapiti, moose, reindeer and caribous, or their fawns, October 1 to December 1. Grouse, partridges, prairie chickens and pheasants, September 1 to December 1. Woodenck8, plovers (except golden plovers), snipes and sandpipers, August 1 to January 1. Any kind of wild duck, sea duck, widgeon, teal, wild swan, or wild goose, except the variety of wlld goose comnonly known as "the wavey" or "snow goose," September 1 to May 1. Nests and eggs of game birds protected. Otters, fishers, pekans, beavers, muskrats and sables, October 1 to May 15. Martens, November 1 to April 15. Trapping and netting, excepting of otters, flshers, beavers unskrats, martens and pekans, prohibited. Poisons, batteries, swivel guns, sunken punts and night lights and spring guns prohibited. Exportatlon of game birds and animals, without a permit, prohibited. Hunting on lands without permission of owner forbidden. Insectivorous birds, nests and egg protected. Sunday shooting prohibited. Transportation of game forbidden during the close season. Non-residents prohibited from shnoting unless provided witl a license (costing \$25). Pickerel (doré), May 15 to April 16. Speckled trout, January 1 to October 1. Explosives and poisons prohibited.

BIITISH COLUMBIA.-Deer, elks, relndeer, caribou, wountain goats, mountain sheep and hares, August 15 to December 20.:. Cow elks protected at all times. Grouse, partridges, prairie fowl, California and Virginia quails, robins and meadow larks, September 1 to February 1. Wild ducks, September 1 to March 1. Cock pheasants, October 1 to February 1. Hen pheasants protected at a!l times. Night hunting prohibited. Hounding deer prohibited except east of the Cascades. Cock pheisants and yuails are protected on the inainland until Sentember 1 , 1894 ; may be shot as above stated on Vancouver Island. Insectivorous birds and their nests protected. Gulls protected in the harbors and tributary streams of Victoria, Eifuimault, New Westminster, Nanaimo or Vaucouver. Skin hunting and exporting prohibited. The sale of any pheasant, fawn or deer under the age of twelve months, and does of any age, prohibited. A non-resident must procure a license to shoot game animals. Trout, March 15 to October 16. Nets, weirs, seines, or similar devices, explosives, drugs and poisons prohibited

NEW BRUNSWICK.-Moose (bull), deer and caribou, September 1 to January 15. Cow moose are protected absolutely. Partridges or ruffed grouse, September 20 to Dacember 1. Snipes, September 15 to March 1. Woodcocks and teal ducks, September 1 to Decembur 1. Geose, ducks and brants, September 1 to May 1. Hares an 1 rabbits, Septomber 1 to March 1. Mink, otter, fisher, sable and beaver, September 1 to May 1. Night hunting by artificial light and use of swivel or punt gun prohibited. Non-residents prohibited to hunt without a license. Hounding moose, caribou and deer prohibited. Sunduy shooting and exportatiou 
of game prohlbited. No person or party is allowed to alli zaore than one monse, two caribous or three red deer durlnz any one season. Sea-gutls protected in the parlsh of Grand Manan. Bass, October 1 to March 1. Bars of less than two pounds, protected. Salmon, March 1 to Angust 15. Fly fishlng for salmon, August 15 to February 1. Speckled trout and land-locked salmon, May 1 to September 15. Exploslves, nets, traps, etc., prohiblted.

NOVA SCOTIA.-Moce and caribou, September 13 to February 1. Hares or rabblte, Octobar 1 to March 1. Otter and mlnk, November 1 to May 1. Beavers, and furred anlmale, November lto Aprll 1. Gronse or partrldge, September 15 to January 1. Woodcocks, sulpes and teal ducks, Auguat 20 to March 1. Blue-wing sad black ducks, Angust 1 to A pril 1. Wundcocks must not be shot before sunrise nr after sunset. No person shall kill more than two mоoвe or four carlbou ln one seasin. Pheasants protecterl. Song and Insectivorous blrds protected. Tionrestdents prohiblted to hunt without a liceive. Exportatlon of game or hides prohlblted. l3ass fishing at any tIme with hook and IIne only; bass under I wo pounds welght protected. Salmon, Mnrch 1 to Auguat 15; fly fishlng, February 1 to Auguat 15. Speckled trout, lake trout or landlocked saltaon, April 1 to October 1. Exploslves, trups, nets, etc., prishibltod.

NEWFOUNIILANI) Mouse and elka protected nntil Jasuary 1, 1 He6. Carlbon. Oetober 1 to Fobruary 15. Not twore than Ave stag and three hlail carlbou allowed to be killed in nuy nae senwa. leer. Jaly 15 to March 1. Rabbits or hnres, September 1 to March 1 Otters and heavers, October 1 to April 1 . Curlews, plovers, snipen, or other wild or migratory birds (exceptlag wlld geese), August 20 to Jnnuary 12. Grouse or partrldge, September 15 th Jaunary 12. Wild geene. August 29 to April 1. Cnpercallzle protected. Licese for non-reslientw requlred. Sunday shootlng and exportation of garne prohilbtes. Trout, char, whitedah, land locked enlmon, or any fresh water or any mikrat iry flsh, December 1 to September 15. Salmon, Mas 1 to Siptember 10. Viets, traps, welrs, exploslves, etc., problulted. Id cense requitrel.

NORTHWEST TERKITOKILs.-Elks, moone, carlbou, mntelopes, deer, mountain sheep or gont, hares, Reptember 1 to February 3. Snlpen, August 13 to Jas 2. Groune, partridzen, pheasauta, pralrle chlckeus. September 1 to February 1. Ducks and geese, August 15 to May 15. Suarlng, trapplag, balting, etc., prolitblted. Exportation prohlblted. Game may be kllted nt any thae to prevent mtarvation, but not more thau Immediate want demands. Plckerel, May 15 to April 15 Speckled trout, Janunry 1 to October 1. Exploslrea, nets, e!c., prohlbited.

- PRINCE EDWARD'S ISLAND - prartrldges or ruffed grouse, October 1 to February 15. Wonlcocks and snipes, A ugust 20 to Janus:y 1. Ducks, Augugt 10 to March 1. Night obootlng, sneak basat, or any almllar dovices, prohibited. Trout, December 1 to October 1, with hook and line only. 
IiULE 6. Use of Second Barrel.-Where special matches are arranged, allowing the use of both barrels at single birds, a kill or break with the second barrel shall be seored one-half.

RuLE 7. Scoring Incorrect Handicap.-No member is to shoot at a distance nearer than that at which he is handieapped. If he does so, the first time the shot shall be seored "no bird;" the second time it shall be scored a "lost bird:" and the third time he shall forfeit all rights in the contest, and be harred from all other contests during the same meeting, and be subjeet to such additional înes and penalties as the Constitution and By-Laws may provide.

Ril.: 8. Closing of Entries. - All entries shall close at the firing of the first guin. In large international or interstate tournaments, all entries for the first inatelı each day shall be made before $6 \mathrm{P}$. M. of the day preceding the shoot. by depositing 10 per cent of the entrance fee, which shall be forfeited to the nianagement if the entry is not completed before the firing of the first gun.

RULE 9. Class Shooting.-All sweepstakes sliall be Class Shooting unless otherwise specified.

Rul.E 10. Namies Claimed.-The Seeretary shall keep a book in which he shall reeord the names of all the members who desire to shoot under an assumed name. and record the name assumed by each. He shall make a charge of 50 cents, and no more, for each name recorded. No two members shall shoot under the same assumed name. The Secretary may, at the request of a member, issue the handicap card to him, hearing his assumed title only.

RUIE 11. Score with Ink only.-All scoring shall be done with ink or indelible peneil. The scoring of a "lost bird" shall be indieated by a "0;" of a "deal" or "broken" bird by a "1."

\section{ART, III.-THE TRAPS.}

Ru1.E 12. Arrangement of Traps.-Five traps shall be used. They shall be set level upon the ground, without any inequalities of setting in either, in an are of a circle, five yards apart. The radins of the eirele shall be eighteen yarils. The trajs shall be numbered from No. 1, upon the left, to No. 5, upon the right, consecutively. In all traps, except No. 3 , the fourth notch, or a maximum veloeit p equivalent thereto. shall be used, and the elevation of the projecting arm shall not exeeed 15 degrees, viz.., so as to throw the pigeons from four to fifteen feet in vertical height above the level of the trap bottom. In trap No. 3, the thircl noteh, or a velocity equivalent thereto, shall be used, with the same elevation.

RULE 13. Setting of Traps.-A straight line shall be drawn from the seore, at eighteen yards in the rear, to trap No. 3 , and extended to a point not further than seven yards in front of same. Traps Nos. 1 and 5 shall be set to throw the birds across this line, the crossing point being anywliere within the seven yards point in front of trap 3 . Trap No. 2 sliall tlırow in a direetion left half quartering from the score; tra] No. 4 shall throw in a direction right lialf quartering upon the seore; and trap No. 3 shall throw straight-away.

If, after such setting of the traps, the birds, for any reason, take other directions, they shall be considered fair birds.

Rurf 14. Pulling of Traps.-When the shooter calls "Pull" the trap shall lie instantly sprung, or the bird may be refused. If pulled without notice, or more than one bird loosed, the shot may he refusel; but, if taken it is to be seored. If the shooter fails to shoot when the trap is properly pulled, it must be scored a lost bird.

RuLE 15. Position of Puller.- The trap-puller shall stand from four to six fect belind the shooter, and sliall use his own discretion in regard to which trap shall be sprung for eaeh shooter, but he shall pull equally and regularly for all shooters.

RULE 16, Scrrens, Netting, Trench.-No sereens or netting sliall be used; "back stops" may he provided for trappers not to exceed ten yards from the end trajs. and not to exceed three feet in heiglit.

But, when the grounds permit, a trench may be dug to shield the trapper. without obstructing the view of the trajs from the slooter.

RUIE 17. Double Birds, Trap Setting.-Doubles shall be thrown from traps Nos, 2 and 3. 
Trap No. 3 shall be set at about fifteen degrees elevation; trap No. 2 at about twenty degrees elevation, in double bird shooting; and trap No. 4 when used for shooting off ties in doubles, shall be set at about the latter elevation.

Rule 18. Ties and Traps for Ties.-Ties on single birds shall be thrown from traps Nos. 1, 2, and 5 .

Ties on double birds from traps Nos. 3 and 4.

ART. IV.-THE GUN.

RULE 19. Position of Gun.-The gun shall be held below the arni-pit, until the shooter calls "Pull;" otherwise, if challenged, the shot shall be declared a "lost" bird, whether hit or missed.

RULE 20. Loading of Gun. - Charge of powder unlimited; charge of shot not to exceed 11/4 0z., Dixon's standard measure, No. 1106 "dipped" measure. Any shooter using a larger quantity of shot shall forfeit all entrance money and rights in the match, and shall be subject to further action by the management. as provided in the Constitution and By-Laws.

RULE 21. Handicap of Gun.- No guns larger than 10 bore sliall be allowed. Guus of 12 gauge weighing 8 pounds or under, shall be allowed two yards. Guns of smaller calibre than 12 gauge shall be shot at the same rise as the latter.

\section{ART. V. -THE INANIMATE TARGET OR CLAY PIGEON.}

Rule 22. Broken Birds.-No clay pigeon shall be retrieved to be examined for shot marks. A clay pigeon, to be scored broken, must be broken so as to be plainly seen in the air; that is a piece must be clearly and perceptibly broken from it in the air by the shot, before it touches the ground.

RULE 23. Lost Birds.-A. All clay pigeons not loroken in the air as above defined, and not ruled as "no birds," shall be scored lost.

B. When shooting at single clay pigeons, one barrel only sliall be loaded; should more than one barrel be loaded, the shot shall be scored lost.

RULE 24. Imperfect or "No Birds."-If a clay pigeon be broken by the trap, it shall be optional with the shooter to accept it; if he accepts, the result shall be scored.

RULE 25. Allowing Annther Bird.-The shooter shall be allowed another clay pigeon under either of the following contingencies:-

A. In single bird slooting, if two or more are sprung instead of one.

B. If the pigeon is sprung before or at any noticeable interval after the slooter calls "Pull."

C. If the pigeon does not fly twenty-eight yards from its trap, passing over a line (imaginary), at a distance of ten yards from the traps, and four feet high at the latter distance. The spirit of this rule is to this effect: that the bird shall attain an elevation of not less than four feet within ten yards from the trap.

D. If the shooter's gun, being properly loaded and cocked, does not go off through any cause whatever, except througli the fault of the shooter.

E. If a pigeon is thrown so that to shoot in proper time it would endanger life or property.

But if the shooter, in either of the foregoing contingencies, fires at the pigeon, he is to be deemed as accepting it, and the shot must be scored according to its results.

Rule 26. Double Birds.-A. In case one be a fair bird and the other an imperfect or no bird, the shooter sliall shoot at a new pair; both bircls must be sprung at once, otherwise they shall be "no birds."

B. If a shooter fires both barrels at one bird in succession, they shall be scored lost.

C. In double bird shooting, in case of misfire of either barrel, through no fault of the shooter, he shall shoot at another pair.

$$
\text { ART. V̈I. -RISES AND TIES. }
$$

RuLE 27. The Rise,-The rise, in championship matches and sweepstakes, where no handicap has been recorded, wlịen ten bore guns are ísed, shall be 
eighteen yards in singie, and fifteen yards for double clay pigeon shootlng. When ties are shot off, the rise shall be increased two yards until the limit of the handicap is reached. See handicap rules.

RULE 28. Ties. - Ties shall be shot at singles at three birds each, and at doubles at one pair.

Ties in cliampionship matches shall be shot at five singles (thrown from five traps) and two doubles.

RULF 29. Time of Shooting Ties.-All ties shall be shot off on the same grounds, immediately after the match. if they can be concluded before sunset. If they cannot, they sliall he concluded on the following day, unless otherwise directed by the judges. This, however, shall not prevent the ties from diviring the prizes by agreement. Should one refuse then the tie must be shot off. Any one of the persons tieing, being absent thirty minutes.after the time agreed upon to shoot them off, without permission of the judges, shall forfeit his right to shoot in the tie.

RuLE 30. Extreme Limit Tie,-Wlien a shooter is to shoot off a tie, who has previously thereto been handicapped to the extreme limit, he and his opponents shall shoot in the tie at the same distance they each occupied when it occurred.

\section{ART. VII.-TEAM SHOOTING.}

RULE 31. What Constitutes a Club.-The only club which will be recognized by the Association for the purpose of contests, is a club which lias been duly organized, with the ușual officers, and a bona-fide membership of permanent standing, which maintains its organization by stated meetings and practical work. No clubs ean be extemporized and admitted solely for the purpose of shooting in contests.

RuLE 32. Age of Clubs and Members.-Clubs entering teams must be known as regularly orgapized gun clubs at least one month previous to the tournament; members of entered teams must be in gond standing the same length of time, and be endorsed by the President and Secretary of their respective clubs. Shooters belonging to two or more clubs must shoot with their home clubs, and can shoot with one team only.

RULE 33. Order of Shooting. - The teams, in team shoots, will be called to the "score" in the order designated by the Executive Committee; said order will be determined by the dates of original entry, teams being allowed to choose accordingly; the members of the tean will be called to the "score" in the order designated by their respective captains, each memher shooting at five single birds in succession, and then (when all the teams have finished shooting at single birds) the members will, in a similar manner, finish their scores at the double birds.

Rule 34. What Constitutes a Team.-In team championship matches, teams of three to five must be residents of the same state, and in twin team championship matehes, both must be residents of the same county or parish. Any State or county can enter as many teams as they see fit. In team or club match, other than championships, there shall be no restrictions as to residence of members excepting as stated in the program.

RULE 35. No Division of First Championship Prize.-In all championship matches, whether teams or individuals, there shall be no division of prizes or purses among the first scorers or winners of first championship prizes, money or badges, under penalty of expulsion from the Association.

$$
\text { ART. VIII.-PURSES. }
$$

RuLE 36. Division of Purses.-In sweepstake mrateles, if the number of entries is less than twelve, the net purses shall be divided in two sums, viz., sixty per cent and forty per cent: and if the number of entries is over twelve and less than forty, the net purses shall be divided into three sums, viz.., fifty per cent, thirty per cent, and twenty per cent. If the number exceeds forty, the net purses shall be divided into four sums, viz., forty per cent, thirty per cent, twenty per cent and ten per cent.

RULE 37. Association Percentage.-In all tournaments conducted by the Association, five per cent shall be first deducted from all purses for the 
benefit of the Association; clubs shall dedust two per cent, in club matches, should the club so elect.

Rule 38. Paying for Bircls.-The price of birds shall be extra, excepting in miss-and-out matches, where it shall be deducted from the entrance purse.

Rule 39. Guarantecd Purse.- Where a purse is guaranteed by the Association, if the entrance fees collectively exceed the gitaranteed purse, all such excess shall accrue to the guarantors, viz., the Association; if less, then the Association shall supply the deficiency. Purses mentioned in the program are not guaranteed, unless especially so stated.

\section{ART, IX.-HANDICAPS.}

RULF 40. No Handicaps for Championships.-In championship contests there shall be no liandicap, except for guns; nor shall winners of such contests in team championships be handicapped on account of such winning.

RULE 41.-Permanent Handicap. - There shall be a Permanent Handicap for each shooter in all other than in championship matelies. This handicap shall be made by the Executive Committee, who, immediately after each inter. national or interstate tournament, sliall classify every participant therein, and assign to him a liandicap which may range from fifteen up to, but not exceed, twenty yards, for singles, and tliree yards less for doubles. Such handicap shall attach to sucl shooter tliereafter (until altered) in every tournament and match in which he sliall engage, when lie is shooting in any Association sweepstakes; and he must daily legin his shooting at this liandicap.

RULE 42. Temporary Handicap.-In addition to the perinanent handicap there shall be a temporary daily liandicap, as follows: If a shooter, having already a Permanent Handicap, sliall become a winner in a daily shoot, he shall be handicapped because of such winning, in accordance with tlic following rule: All winners or dividers of first money sliall be handicapped two yards; winners or (dividers) of second money sliall be handicapped one yard; inaximum handicap, 22 yards. 'That is to say, if by the scorer's card it appears he is a winner or divider of tirst money, he sliall be handicapped two yards, and lf second money, one yard. Winners of third money are not to be handicapped for such winning. Upon presenting the scorer's card, which entitles thle shooter to payment of his winnings, the executive officer shall, when paying, mark upon the shooter's handicap card the temporary handicap thus made, which shall govern for the remainder of that ulay. Provided, liowever, that in no event shall the maximum of the permanent and temporary handicap combined exceed 22 yards for "singles," and three yards less for "doubles." If the shooter still continues to win at his maximum handicap, the other shooters shall step in towards the traps, the same distance that the successful shooter would have otherwise been placed back.

Rule 43. New Members' Handicap.-New members, whose shooting is unknown, shall be handicapped for the first time indicated in Rules 21 and 27 , though the Chief Executive Officer shall be authorized to change same, at any time during the tournament, after his present match.

RULE 44. Non-Winners' Match Handicap.-Winners in sweepstake matches which are open only to non-winners in previous program matches, shall not be handicapped on account of said winnings in the future progran matches of the same tournament, but said winners sliall be handicapped in all extra matches, whether shot at the main five traps, or at any extra traps which may be in use on the grounds.

RULE 45. Extra Match Handicap.-All matches duly announced in the program are termed "Program Matches;" all others "Extra Matches," whether sliot at the main five traps, or at any other traps in use on the grounds. Winners in all "Extra Matches" shall be handicapped according to the above rules in all subsequent extra matches only.

$$
\text { ÁRT. X.-CARDS. }
$$

RULE 46. Handicap Cards.-The Secretary of the Assoclation shall issue to each member a Handicap Card, which shall beal on its face the name of the shooter, the date of issue, and his permanent handicap, and blanks for temporary handicap lecords and paynient of annual dues. The Secretary sliall 
keep a record of all such cards issued. In the absence of the Secretary, the Cliief Executive Officer of the Association on the grounds of a shoot, shall issue such carl to any member who has not obtained one, and make a duplicate thereof, to be forwarded to the Secretary.

If the permanent handicap is changed by the Executive Committee, the old card sliall be surrendered at the time of issuing the new one.

A permanent luandicap sliall not be changed during a shooting contest.

When a shooter is called to the score, he shall show lis Handicap Card to the scorer (who will mark the liandicap on the score book), and also to the referee. score.

Shooter's must provide theniselves with Handicap Cards before going to the

The Chief Executive Officer shall countersign all Handicap Cards issued by the Secretary. At the beginning of a tournament, shooters shall present their cards to the Executive Officer to be countersigned.

livle 47. Pigeon Cards.-The Secretary shall provide the Chief Executive Officer with "Pigeon Cards," which for live pigeons, shall bear the numbers from one to twenty, inclusive, and sliall be sold by the Executive Officer for $\$ 5$; and which. for clay pigeons or other artificial targets, shall be numbered from oue to thirty-three inclusive, and shall be sold for \$1.50. The same shall bear the signature of the Secretary and the Chief Executive Officer. The scorer will punch these before the pigeons are used. All shooters must provide themselves with their respective cards before going to the score, and unused portions thereof will be redeemed at the rate at which they were issued.

KuIs 48. Winners' Cards.-At the conclusion of each match, the scorer shall announce the winners, and shall fill ont a card containing date, place and number of the match, name of the winner, whether 1st $2 d$, or $3 d$, etc., number of entries, amount of entrance fee, percentage to be d ducted, and sign it as scorer. The winner shall present it to the Executive Oficer, who, after adding the Temporary Handicap to his record card, shall thereupon pay the amount stated, and make a record of it in his minute book. A jy complaint as to the imount stated must be made before receiving paymeat. These cards must subseguentiy be transmitted by the Executive Officer to the Secretary.

\section{ART. XI.-PROHIBITIONS AND FIN ES}

RULE 49. Prohibitions.-None but members shall shoot in any contest, unless otherwise announced in the special rules by the Executive Committee.

Rule 50. Wire Cartridges Prohibited. - Wire cartridges and concentrators are, on the ground of safety, strictly prohibited; dlso the admixture of dust, grease, oil, or any other substance to the shot.

RULE 51. Muzzle-Loaders Prohibited.-On the ground of safety, and for the general convenience of the shooters, muzzle loaders are prohibited.

Rule 52. Fines. - A fine of one dollar, to be added to the purses, shall be rigidly exacted for any of the following acts of negligence:-

A. Pointing a gun at any one under any circumstances.

B. Firing off a gun, except when the shooter has been called to shoot, and is at the score.

C. Closing a gun with cartridge in before arriving at the score, or pointing toward the shooter or spectators when in the act of closing it.

D. Quitting the score without extracting a loaded cartridge unfired.

E. Having a loaded gun anywhere on the ground, except when at the score.

RuLE 53. Fines for Boisterous Wrangling.-Should any contestant attempt to take any undue advantage of a shooter when at the score, in order to cause him to lose a bird, or should any contestant create or participate in any dis. turbance, or loud, boisterous wrangling during a shoot, ?. sliall he fined not less than \$5, or expelled from the Association, in the manner provided for in the Constitution and By-Laws.

Rule 54. Bribery. - Any slooter convicted of an attempt to lurbe, or in any manuer influence tlie trappers, judges, scorers, referee or pullers, shall be barred from all further contests during the tournament, and shall be expelled from the Assoclation. 
ART' XII.-EXECUTIVE COMMITTEE.

RULE 55. Changing Sweepstakes.-Through the Chief Executive Officer, the Executive Committee reserve the right to add io, change or omit, any sweepstakes or matches.

RULe 56. Barring Professional Shooters.-They reserve the right to bar out, upon request of any two amateur shooters in the, matel, any publicly known professional shooter, and also any slooter who is well known to them to be ungentlemanly or disputatious.

RULE 57. Recognize no Bets.-They will not recognize bets, nor decide any matters arising from them. Neither shall judges or referees do so.

RULE 58. Changing Rules.-Rules announced to govern tournament shall not be changed within thirty days of the date of the tournament; but while a tournament is proyressing, rules may be made to govern future tournaments.

RULE 59. Duties of Chicf Exeoutive Ufficer.-All entrance moneys shall be held by the Chief Executive Officer representlng the Association on the grounds. He shall divide the purses, retaining the percentages. . He shall mark with ink on the handicap card of the winners the date and the temporary handicap for the day, and shall make a record thereof in his daily minute book.

He shall take charge of the score books every night during the tournament.

He shall have authority to employ such subordinates as he may require.

He shall countersign the handicap cards. He shall have authority to inange the permanent handicap cards of unknown members.

He shall sell the "Pigeon Cards" and redeem any unused parts thereof.

\section{ART. XIII.-NATCHES PER TELEGRAPH.}

RULE 60. Teams or individuals may arrange matches, or the Association nay arrange same, to be shot by each at their own respective localities, without coming together, upon complying with the following conditions, viz.:-

The entrance fee shall be sent by mail, to the Secretary of the Association, to reach him before the shooting begins. If the entrance fee is not sent by mail, it may be sent by telegraph one hour before the shooting begins. Any person hot a member, who desires to enter, may send ly mail or telegraph one hour before the shooting begins, an initiation or member's fee of $\$ 5$, and the entrance fee besides.

All the rules heretofore stated shall apply equally to such matches. Members shall shoot at their permanent handicaps. Those who have no handicap record, shall shoot at the usual distance, eighteen yards, etc. The result of each score must be telegraphed as the same is made, to the Secretary of the Association. The scores must also be mailed to him the same day; and thefr accuracy certified to by the President and secretary of the local club, or by two disinterested and responsible witnesses who saw the shooting, and who are members of the Association.

Ties shall be shot off, under these rules, upon the twentieth week day thereafter.

The Executive Committee of the Association will duly announce the result, and decide upon any controverted points. The committee shall have full power to make inquiry as to the accuracy of the scores as reported, and to award the money according as the facts may appear.

ART. XIV.-THE LIVE PIGEOX.

The following rules, (in addition to and modification of the preceding rules), apply to live pigeon matches only:-

RULE 61. The Traps, Rise, Boundary, Challenged Birds.-All live birds shall be shot from the ground traps, which shall be set five yards apart. Rise twenty-five yards. Use of one barrel only. Boundary unlimited. In case of challenged bird the shooter allowed three minutes to gather it.

RULE 62. Birds on the Wing.-In double bird shooting, the bird shall be on the wing when shot at. A bird shot on the ground shall be scored lost. Double birds to be shot at twenty-one yards rise, boundary unlimited; five minutes allowed to gather birds if challenged. 
liv1.1: 63. Ties.-On single birds, twenty-five yards rise; doubles at twenty-one yards rise:

RULE 64. Lost Birds, No Bird.-If a bircl is slot at, by any person other than the shooter at the score, the referee shall decide whether it shall be scored lost, or whether he will allow another bird. When traps are sprung, should a bird refuse to fly after a reasonable time, the shooter may call "no bird."

KuLE 65. Gathering Birds,-It shall be optional with the shooter tc gather his own birds or alp point a person to do so for lim. In all cases the birds ulust de gattlered ly hand, withonit auy'forcible means, within three minutes from the time it alights, or it shall be scored a lost bird. All live birds must show soine shot marks if challenged. 

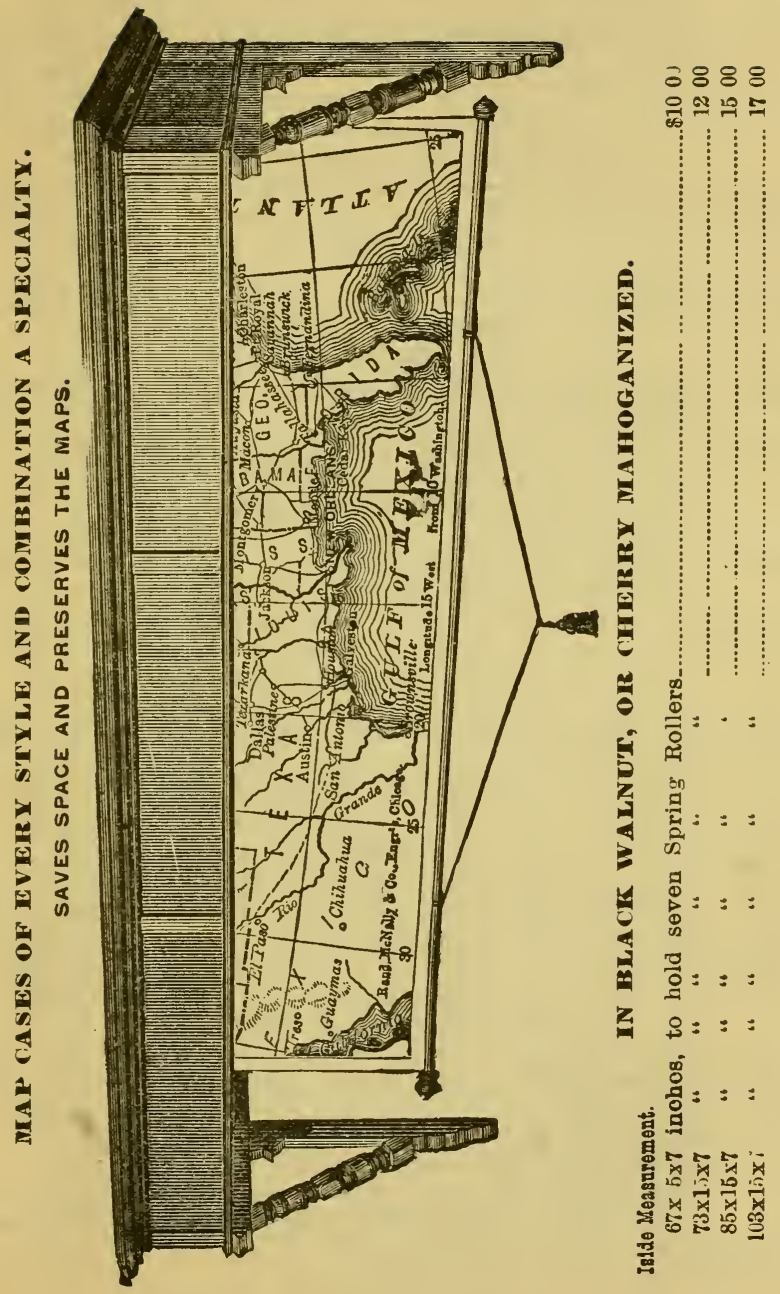


\section{PRINCIPAL THEATRES.}

GIRAND OPEIRA HOUSE, 516 Market St. ADMIISSION:

Seats 2,250

Box.....\$12.00 and $\$ 10.00$

Parquette......... 1.00

Parquette Circle....\$ $\$ 1.00$

Balcony .......75 and 50

GEO. MCMANUS, Business Manager.

THE HAGAN, 10th and Pine Sts. Seats 2,250 ADMISSION:

Box, $\$ 10$; Lodge Box, $\$ 6.00^{\circ}$ Parquette Circle.... $\$ 1.00$ Parquette........... $1.00 \quad$ Balcony.........75 \& 50c HAVLIN \& HAGAN, Managers.

OIJ MIPIC, 107 South Broadway.

Seats 2,409 ADMISSION :

Boxes .........\$10.00 Parquette Circle....\$1.00 Parquette........ $1.00 \quad$ Balcony......75 and 50c PAT SHORT, AYanager.

POPE's, 9 th and Olive Sts.

Seats 2,300 ADMISSION :

Boxes..........\$10.00 Parquette Circle..75 \& 50c Parquette.......... 75̆c Balcony.........25 \& 35c HALLIN \& HAGAN, Munagers.

I A $Y \mathbf{I N} S \mathbf{S}, 6$ th and Walnut Sts.

Seats 2,200 ADMISSION :

Box ................ Parquette Circle..75 \& 50c Parquette........ 75c Balcony....... 35 \& 25c J. H. HAVIIN, Manager.

STAIDAND, 7th and Walnut Sts. Seats 2,250 ADMISSION :

Box...........\$3.00 Parquette Circle......50c

Parquette......... $75 \mathrm{c} \quad$ Balcony........3 \& \& 25c ED. BUTLER, Manayer.

PIOKXYCIX, 2621 Washington Ave. Seats 1,000

MEMORIAL HALL, 19th and Lucas Place.

ADDINGTON HALL, 1\%th and Olive Sts.

ESHER's, r12 st. Charles st.

LAFAYETTE PARK, 1749 Second Carondelet Ave

LONDON, 24 South Fourth street.

PALACE THEATRE, $620 \mathrm{kIm}$ Street.

URIG'S CAVE, 2600 Washington Avenue. 


\section{GENERAL ATLASES OF THE WORLD.}

Appleton's Hand Atlas of the United States, just out, containing nicc page maps of each State, giving with each map a descriptive history of each State, with late statistics and resources, etc.; in cloth..................... $\$ 1.50$

Berhans' Physical Atlas, 93 colored sheets, several hundred maps, 2 vols., half Russia ........................ 55.00

Black's Now Atlas of the World. American Edition; very coniplete...

Bradley's Large Atlas of the World, very completo in detail

Colton's General Atlas of the VVorld, contains 200 maps and plans, and 130 Imperial folio pages of Descriptive, Historical, Geographical and Statistical ............... 20.00

Cram's A merican Standard Atlas of the World, (subscription) of over 350 pages of Mape and Index, showing all Cities, Towns, Villages, Post offices and Hamlets, giving Banks, Telegraph, Express and Money Order offlces, and population, with index for locating all towns. For Railroad and Express officials, banks, business men, libraries, etc.

Cloth, $\$ 12.50$. Half mo. $\$ 15.00$. Full Russia Gilt Edge... 17.8

Cram's Atlas of the World, (subscription) Universal, Geographical, Astronomical and Historical. Large quarto, $12 \times 14$ inches; 375 pages; embossed and title stamped in gold

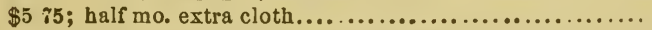

Cram's Unrivaled Atlas of the World (subscription),

12 Xl4 in., : 0u pages: cloth. $\$ 4.25$ : half mo......................

Gray's General Atlas of the World. Large size; half mo........................................ 1800

Johnson (A.IK) Royal Atlas of Iodern Geography with special Index to each map. Folio half Russia; gold edge .................................... 50.00

Johnson's Handy Royal Atlas of Modern Geography. Imperial, 4to; half mo., 45 maps............ 21.00

Mitchell's General Atlas of the World, 107 maps and plans, and a list of Post-offices and Statistical Tables,

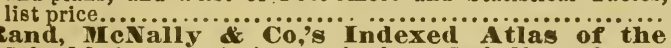
World, (subscription), contains large Scale Maps of every country upon the face of the globe, together with Historical, Statistical and Descriptive Matter, relative to each: Iilus. trated with Colored Diagrams, (send for Descriptive Circular),

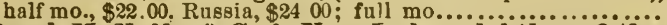

Rand, II Nally \& Co.'s New Indexed Atias of the World. (subscription). Historical and Descriptive, containing Large Scale Maps of every country of the globe, together with Historical and Descriptive Matter relative to each, and giving a ready reference Index; 731 pages; size, 111/2 x141/2 1nches; 82 Donble Page Maps and 518 pages of Index Matter. (8end for Descriptive Circular.) Cloth, \$10.75; half mo., 12.75 full mo. 


\section{THE \\ Favorite Route St. Louis.}

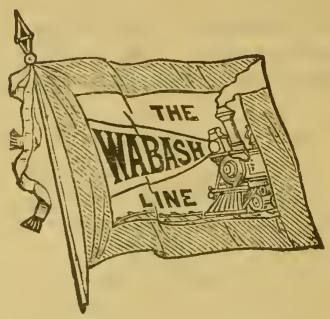

\section{Solid Vestibuled Trains,}

\section{Chicago, Toledo, Detroit,}

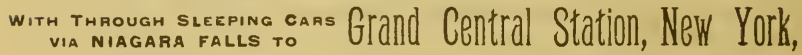
AND TO BOSTON THROUGH THE THEL

Palace Dining Cars

ON CHICAGO, NEW YORK aND BOSTON TRAINE.

Pullman Buffet Sleeping Cars, TO

KANSAS CITY, COUNCIL BLUFFS, OMAHA, DENVER, SALT LAKE, SAN FRANCISCO,

DES MOINES, ST. PAUL, AND

MINNEAPOLIS INITHOUT CHANGE.

Palace Reclining Chair Cars, Seats Free, ON RLL THROUGH TRAINS.

ST. LOUIS TICKET OFFICES:

S. E. Cor. Broadway and Olive Street and Union Depot. 
लन०

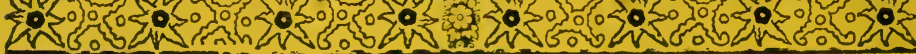

\section{PERKINS \& HERPEL'S}

Mercartile College, Cor. 4th Street and Washington Avenue, ST. LOUIS, MO.

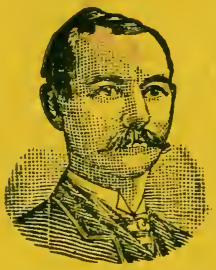

H. C. PERKINS.

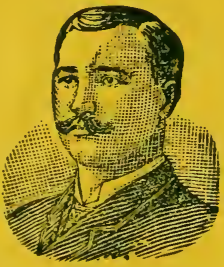

P. J. HERPEL.

* tradividสal thastraction

GIVEN IN BOOKKEEPING, PENMANSHIP, SHORTHAND,

TYPEWRITING, ARITHMETIC,

GRAMMAR, ETC.

Telephone 1027.

Write for Catalogue. 


\section{LIBRARY OF CONGRESS}

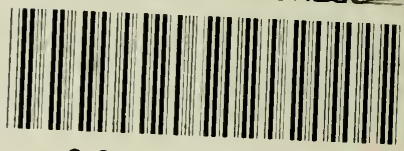

0 0145728022 